PNL-3298

UC-94a

\title{
A Descriptive Analysis of Aquifer Thermal Energy Storage Systems
}

R. W. Reilly

June 1980

Prepared for the U.S. Department of Energy under Contract DE-AC06-76RLO 1830

Pacific Northwest Laboratory Operated for the U.S. Department of Energy by Battelle Memorial Institute 


\title{
NOTICE
}

This report was prepared as an account of work sponsored by the United States Government. Neither the United States nor the Department of Energy, nor any of their employees, nor any of their contractors, subcontractors, or their employees, makes any warranty, express or implied, or assumes any legal liability or responsibility for the accuracy, completeness or usefulness of any information, apparatus, product or process disclosed, or represents that its use would not infringe privately owned rights.

The views, opinions and conclusions contained in this report are those of the contractor and do not necessarily represent those of the United States Government or the United States Department of Energy.

\author{
PACIFIC NORTHWEST LABORATORY \\ operated by \\ BATTELLE \\ for the \\ UNITED STATES DEPARTMENT OF ENERGY \\ Under Contract DE-AC06-76RLO 1830
}

\author{
Printed in the United States of America \\ Available from \\ National Technical Information Service \\ United States Department of Commerce \\ 5285 Port Royal Road \\ Springfield, Virginia 22151
}

Price: Printed Copy $\$$

*: Microfiche $\$ 3.00$

NTIS

*Pages Selling Price

001-025 \$4.00

026-050 \$4.50

051-075 \$5.25

076-100 \$6.00

$101-125 \quad \$ 6.50$

126-150 \$7.25

$151-175 \quad \$ 8.00$

$176-200 \quad \$ 9.00$

201-225 \$9.25

226-250 \$9.50

$251-275 \quad \$ 10.75$

276-300 \$11.00 
PNL -3298

UC-94a

\section{3}

A DESCRIPTIVE ANALYSIS OF AQUIFER THERMAL ENERGY

STORAGE SYSTEMS

R. W. Reilly

June, 1980

Prepared for

the U.S. Department of Energy

under Contract DE-ACO6-76RLO 1830

Pacific Northwest Laboratory

Richland, Washington 99352 


\section{ACKNOWLEDGEMENT}

This report includes input from many staff members of the Pacific Northwest Laboratory's Seasonal Thermal Energy Storage Program, especially P. L. Hendrickson who wrote most of the legal and institutional chapter, and H. L. Parry who had considerable input into the technical feasibility chapter. 
TABLE OF CONTENTS

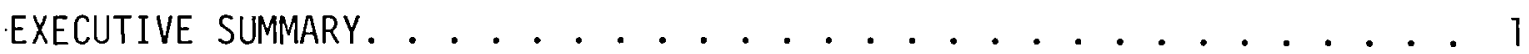

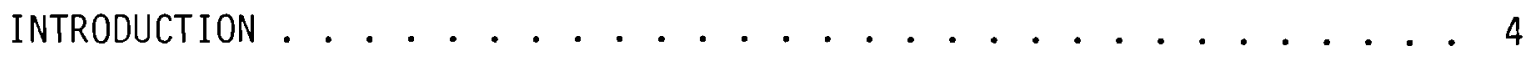
SYSTEM DESCRIPTION . . . . . . . . . . . . . . 10

THE BASIC MODEL . . . . . . . . . . . . . . 10 OTHER CONFIGURATIONS. . . . . . . . . . . . . . 11

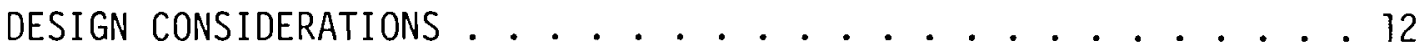
AQUIFER THERMAL RECOVERY EFFICIENCY . . . . . . . . . 14 HISTORICAL EXPERIENCE WITH ATES AND RELATED TECHNOLOGIES. . . . 15 TECHNICAL FEASIBILITY. . . . . . . . . . . . . . 17 ENERGY COLLECTION CONSIDERATIONS. . . . . . . . . . 17 STORAGE CONSIDERATIONS. . . . . . . . . . . . . 19 TRANSPORT AND DISTRIBUTION CONSIDERATIONS ......... . . 23 END-USE CONSIDERATIONS. . . . . . . . . . . 23 ENVIRONMENTAL CONSIDERATIONS . . . . . . . . . . . . 25

ENVIRONMENTAL ADVANTAGES. . . . . . . . . . 25 POTENTIAL ENVIRONMENTAL PROBLEMS. . . . . . . . . . . 26 OTHER SUBSURFACE CONCERNS . . . . . . . . . . . 28

CONSIDERATIONS FOR ENVIRONMENTAL ASSESSMENT AND MONITORING. . . . 30

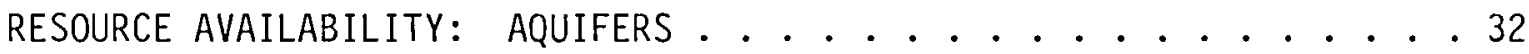
AQUIFER SUITABILITY . . . . . . . . . . . . 32

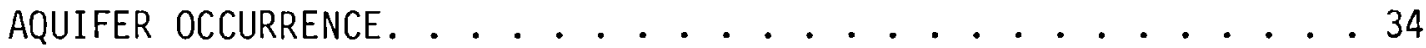
RESOURCE AVAILABILITY: ENERGY SOURCES . . . . . . . . . 37

ENERGY SOURCES. .......................... 37

ENERGY SUPPLY ........................ 41 
SYSTEMS ECONOMICS. . . . . . . . . . . . . . . . 43

GENERAL COST CONSIDERATIONS . . . . . . . . . . 44

ENERGY COLLECTION COSTS . ..................... 46

STORAGE-RELATED COSTS . . . . . . . . . . . . 47

FLUID TRANSMISSION COSTS. . . . . . . . . . . 48

END USE-RELATED COSTS . . . . . . . . . . . . 48

EXAMPLES OF ATES COST EFFECTIVENESS . . . . . . . . 49

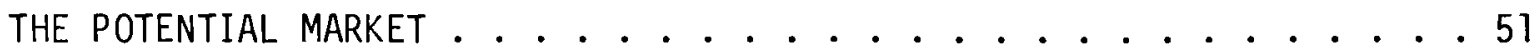

THE POTENTIAL FOR DISTRICT HEATING. . . . . . . . . . 52

THE POTENTIAL FOR INDUSTRIAL PROCESS HEAT . . . . . . . . 53

POTENTIAL FOR AGRICULTURAL USE. . . . . . . . . 56

MARKET PENETRATION RATES. . . . . . . . . . . . 57

LEGAL AND INSTITUTIONAL ISSUES . . . . . . . . . . . 59

REGULATORY REQUIREMENTS ASSOCIATED WITH ENVIRONMENTAL

PROTECTION DURING STORAGE ..................... 59

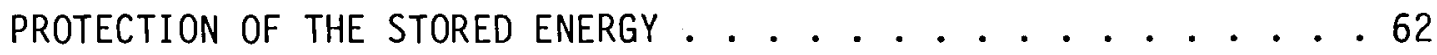

POTENTIAL LIABILITY ASSOCIATED WITH ATES. . . . . . . . . 63

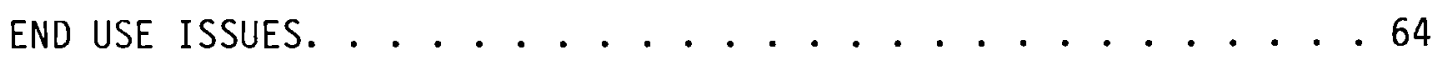

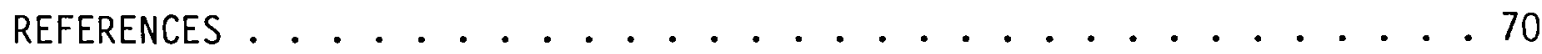




\section{A DESCRIPTIVE ANALYSIS OF AQUIFER THERMAL ENERGY STORAGE SYSTEMS}

\section{EXECUTIVE SUMMARY}

Seasonal storage of thermal energy in aquifers has the potential to make a significant near-term contribution towards relief of the national energy shortage. Winter chill, summer heat, and various forms of industrial waste heat can be stored for future demand, and can thus reduce the need for generating primary energy and lessen the nation's dependence on imported petroleum fuels. It appears that it is technically feasible to supply about $7.5 \%$ of the nation's total energy demand through aquifer thermal energy storage (ATES), with about a third of this energy initially supplied by industrial waste heat. This is purely a technical estimate, with no consideration given to cost effectiveness of ATES systems, or to institutional problems, including the need to amass very large amounts of capital for construction of ATES storage and distribution systems.

ATES appears to be the most promising of the several technologies proposed for long-term (or seasonal) storage of large amounts of thermal energy. A major key to ATES's attractiveness is its simplicity of design and construction. The storage device consists of two ordinary water wells drilled into an aquifer, connected at the surface by piping and a heat exchanger. During the storage cycle water is pumped out of the aquifer, through the heat exchanger to absorb thermal energy, and then back down into the aquifer through the second wel1. The thermal energy remains in the aquifer "storage bubble" until required for use, when it is recovered by reversing the storage operation. For many applications the installation can probably be designed and constructed using existing site-specific information and modern well-drilling techniques.

Another key to the attractiveness of ATES is its potential for costeffective operation. The storage medium, water, is inexpensive. We11drilling and equipment costs constitute the only capital storage expense, and so the cost of the storage container is essentially independent of the amount of energy to be stored. Therein lies the major advantage of ATES over other storage technologies, where cost of the container is typically 
proportional to volume stored. It is likely that initial storage efficiencies of $70 \%$ will be encountered for commercially-sized units. Efficiencies are expected to increase over time, possibly to the $90 \%+$ range, as the aquifer heats or cools.

The potential for cost-effective implementation of ATES was investigated in the Twin Cities District Heating-Cogeneration Study in Minnesota. In the study, ATES demonstrated a net energy saving of $32 \%$ over the nonstorage scenario, with an annual energy cost saving of $\$ 31$ million. Discounting these savings over the life of the project, the authors found that the break-even capital cost for ATES construction was $\$ 76 / \mathrm{kW}$ thermal, far above the estimated ATES development cost of $\$ 23$ to $50 / \mathrm{kW}$ thermal. It appears that ATES can be highly cost effective as well as achieve substantial fuel savings.

There are concomitant benefits. Large-scale ATES development has the potential for improvement of the environment, primarily due to reduced pollution from extraction, refining, and combustion of fossil fuels. Thermal pollution is reduced, and so is the cost of equipment presently required to treat that thermal pollution. The reliability of district heating systems is enhanced.

The potential for market penetration of ATES is immense. Aquifers are estimated to underlie roughly two-thirds of the nation. This figure probably understates ATES's potential because most applications will be in urban/ industrialized regions, which are typically located near productive aquifers. Both winter chill and summer heat are technically feasible energy sources for many parts of the country, and the potential for electrical cogeneration and for capture of industrial waste heat is vast.

Widespread implementation of ATES is not without difficulties, however. The more exotic energy sources present technical problems, and work needs to be done to evaluate the implications of widespread heat storage at depth. Perhaps the most significant barriers to commercialization, though, are institutional. Since this is a new technology, numerous legal questions need to be addressed, including liability for thermal pollution of the 
aquifer and protection of the stored resource from capture by others. Because district heating of residential housing requires extensive pipelines, work needs to be done to develop the means to finance these highly capitalintensive ventures and to create incentives and/or leadership for such developments.

The existing body of information on ATES indicates that it is a costeffective, fuel-conserving technique for providing thermal energy for residential, commercial, and industrial users. The negative aspects are minor and highly site-specific, and do not seem to pose a threat to widespread commercialization. With a suitable institutional framework, ATES promises to supply a substantial portion of the nation's future energy needs. 


\section{INTRODUCTION}

Seasonal storage of thermal energy in aquifers is expected to make a significant near-term contribution towards the energy conservation and fuel substitution goals of the National Energy Plan. Implementing this technology on a large scale will increase the overall thermodynamic efficiency of energy generation in this nation. Moreover, it will enable waste heat and energies of opportunity to be substituted for scarce, costly fuels such as $0 i 1$ and natural gas. It appears that it is technically feasible to supply about $7.5 \%$ of the nation's total energy demand through aquifer thermal energy storage (ATES), with about a third of this energy initially supplied by industrial waste heat. This is purely a technical estimate, with no consideration given to cost effectiveness of ATES systems, or to institutional problems, including the need to amass very large amounts of capital for construction of ATES storage and distribution systems.

An ATES installation in its simplest form is composed of a pair of ordinary water wells drilled into an aquifer (Figure 1). During operation, the ground water is withdrawn from one well, heated (or chilled) in a heat exchanger, and then returned to the same aquifer through the second well. The thermal energy is stored in the aquifer until needed. At recovery, the second well is pumped, and the hot (or chilled) water circulated through a heat exchanger to recapture the stored energy and then returned to the aquifer through the first well. The thermal energy can then be employed for space or process heating (or cooling), thus reducing the need for generation of primary energy. The concept is simple, inexpensive, and relatively efficient.

Like any other energy storage technology, however, ATES is characterized by a net energy loss. About 50 to $90 \%$ of the input energy can be recovered for beneficial use, depending upon the system's design and the aquifer's characteristics. The remainder is dissipated into the earth.

The key to ATES's effectiveness is that the recovered energy is energy that would have been wasted without seasonal storage, generally because no demand existed at the time of availability. This mismatch of energy supply 


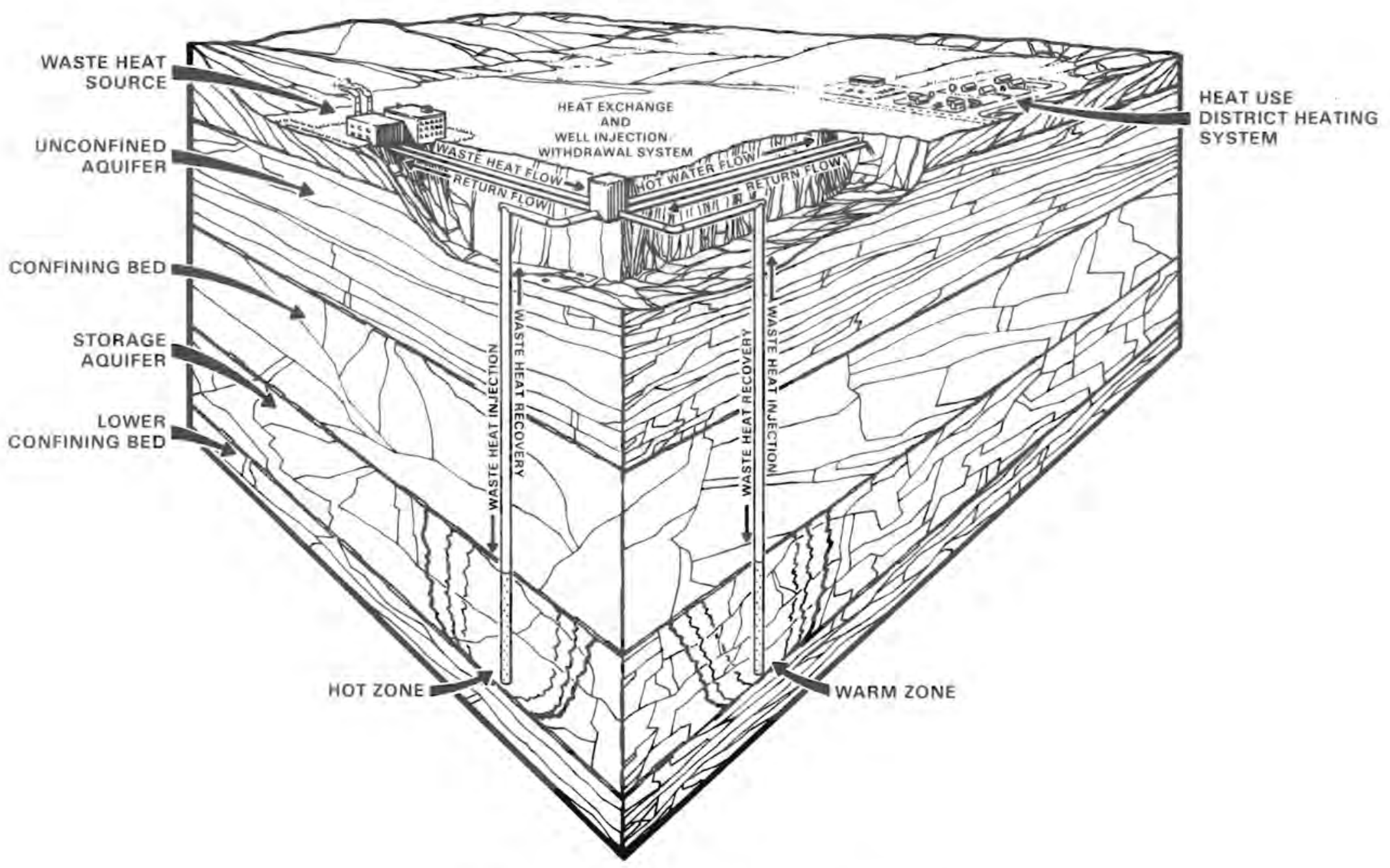

FIGURE 1. Aquifer Thermal Energy Storage 
and demand over time is the pervasive condition that makes ATES attractive. Available energy in this category includes cogeneration, climate-related energy, and industrial waste heat.

Cogeneration is the simultaneous production of electricity and heat at the same facility, generally in constant proportions. It is a desirable mode of energy production because of its high efficiency: about $85 \%$ of the fuel's energy content is made available as electricity and hot water. This compares to an overall generation efficiency of about $33 \%$ in conventional electrical plants. Despite this gain in efficiency, cogeneration is not widespread because the heat is generated according to electrical demand (electricity is the primary product), which seldom coincides with the demand for heat. Hence, there is a constant drawback of too little or too much heat to meet the demand, making the technology impractical for many applications. The availability of an efficient form of long-term storage for large amounts of heat (such as ATES) can make cogeneration attractive for many uses. Even if a storage efficiency of only $60 \%$ is available, the overall efficiency of the cogeneration/storage installation would be about $60 \%$, a considerable improvement over the conventional mode of power generation. (3)

A second example of a mismatched supply and demand is the use of climate energies of opportunity for heating and cooling of buildings. Winter chill is readily available in the form of snow, cold air, or cold surface water. Seasonal storage can make this energy available for summer air conditioning. Likewise, summer heat can be captured for winter heating. In higher latitudes, where winter daylight is limited in extent and intensity, seasonal storage provides the only means of employing solar energy for significant amounts of space heating. In other latitudes it may facilitate the costeffective use of solar energy by reducing or eliminating backup systems normally required for solar installations.

Use of the abundant supply of industrial waste heat is a third area where a major energy source exists but remains untapped because typical use for such heat, space heating, is seasonal. Seasonal storage can enable us to tap this year-round supply, extend its possible applications, and simultaneously reduce the need for expensive heat dissipation equipment at plant sites. 
ATES, one of many seasonal storage concepts under study, appears competitive with, or superior to, other modes of long-term storage for several reasons:

- Capital costs are independent of the amount of energy stored because use of the aquifer is essentialiy free. Instead, storage cost is a function of the rate of injection and withdrawal, since this rate determines the number of wells required, and well-related costs constitute the largest capital cost for a typical ATES installation. Hence, the longer the storage period (for a constant energy flow), the better the relative ATES economic performance.

- Energy is stored as heat or chill. Most waste energy and energy of opportunity exists in this same form of thermal energy, and many of the uitimate uses for the stored energy are in the form of heat or chil1. Avoiding a transformation between energy forms (such as thermal to electric and back to thermal) eliminates the losses inherent in such transformations.

- Water is an inexpensive, widely available storage medium with a very high heat capacity. It is safe, and the technologies for its control are well developed.

- The water is not consumed but is instead available for continuous cycling.

- Aquifers have effective natural thermal insulation.

- Deep aquifers provide safe containment for high-temperature, highpressure water.

- Aquifers are readily available. Approximately two-thirds of the nation is underlain by aquifers.

- ATES readily permits the superposition of short-term storage cycles over the seasonal cycle. This characteristic makes ATES very flexible and suitable for a wide range of applications. 
The concomitant benefits to ATES storage are significant: 1) Utilization of waste heat results in a reduction of thermal pollution and a corresponding reduction in the costs of treating thermal pollution. 2) Using water as a storage medium results in the ability to pump heat economically over long distances, perhaps to 100 miles. (4) 3) Aquifer storage provides greater reliability for district and process heating systems that, without storage, must close down or seek alternative energy sources when the primary heat source is interrupted for maintenance or repair.

Storage of thermal energy in aquifers has received widespread attention only within the last decade since the onset of the "energy crisis." This new interest in ATES is international in scope. Six countries (Denmark, Germany, Sweden, Switzerland, the Netherlands, and the United States), as well as the Commission of European Communities, have signed an International Energy Agency Implementing Agreement targeted on aquifer thermal energy storage research. (5) Considerable ATES-related investigation is being undertaken in these countries as well as in France and the USSR.

The United States' effort is centered in the Department of Energy, Office of Advanced Conservation Technologies, under the Thermal and Mechanical Energy Storage Program. The objective of this program is to develop reliable, cost-effective, and environmentally acceptable energy storage systems to: 1) permit coal, nuclear, and solar sources to be substituted for petroleum fuels, 2) make waste heat utilization feasible for industrial, residential/ commercial, and utility applications, 3) enable solar, wind, and other intermittent energy sources to service continuous energy loads with reduced need for conventionally-fueled backup systems, and 4) provide high-efficiency storage for the electric utility sector. (1)

Aquifer thermal energy storage appears to have the potential to fulfill the first three of these objectives. Before this potential can be realized, however, numerous economic, social, legal, and environmental questions must be answered to the satisfaction of government and private industry. To provide these answers, DOE has instituted the Seasonal Thermal Energy Storage (STES) Program, managed by the Pacific Northwest Laboratory (PNL). 
The STES Program has the overall goal of demonstrating the commercial feasibility of seasonal thermal energy storage. The program emphasizes participation by the private sector in energy storage R\&D activities to ensure early and effective transfer of technology, and to obtain feedback on costs and production methods. Several promising applications of ATES are being cost-shared between the federal government and the developer. Management of these ventures constitutes the bulk of the STES Program. A smaller technically oriented effort is also developing under the STES Program to support program management and in-the-field activities.

This document is an initial effort of that Technical Support Program. It briefly surveys the state-of-the-art ATES technology, evaluating its potential and discussing numerous technical, social, economic, legal, and environmental issues that must be examined. Intended as guidance for potential government and industrial participants, it was generated from an extensive literature review. 


\section{SYSTEM DESCRIPTION}

One key to the attractiveness of the ATES concept is its simplicity of design and construction. For many applications, the total system can probably be planned using existing site-specific information and be constructed using readily available components and drilling techniques from the water well and/or petroleum industries. Numerous extant and historical ATES systems serve as proof of this statement. (These, however, exist largely as a result of happenstance rather than as a predetermined effort to implement the total ATES concept.) For larger systems and ones that utilize extremely hot energy sources or are intended for unknown geologic structures, newly developed data and technical capabilities will be required.

\section{THE BASIC MODEL}

The basic model for the aquifer thermal energy storage system is the doublet: two ordinary water wells drilled into an aquifer. During the storage operation, in-situ ground water is pumped out of the first well, through a heat exchanger where it absorbs heat, and back into the aquifer through the second well. The heat energy is reclaimed by pumping the hot water out of the second well, through a heat exchanger, and then back down the first well. The second well is termed the "hot well" for obvious reasons. The first well becomes a warm well, since the reject water returned to it is typically warmer than the native ground water. The identical technology and aproach can be used to store "chill" thermal energy, with winter chill or some other source providing the energy to be stored.

This doublet configuration averts many potential operational and environmental problems. Since the in-situ ground water is used as the storage medium ( $r$ ather than a newly introduced, chemically different water), the potential for chemical or physical reactions of the water with the aquifer matrix is reduced, and thus a major cause of clogging of the aquifer can be minimized. The doublet concept also precludes any problems with largescale subsidence, since all the water withdrawn is immediately returned to 
the aquifer at the second well. The isolation of the aquifer water in the heat exchanger serves three important functions: 1) It protects the aquifer water from possible contamination that might occur if it were used directly for heating purposes. 2) It allows the use of corrosive aquifer water as the storage medium while a separate noncorrosive fluid is used in the extensive transport and distribution systems; thus only the well and heat exchanger equipment needs to be made of special alloys. 3) It allows the temperatures and pressures in the heat delivery system to be independent of potentially high temperatures and pressures in the aquifer storage system.

\section{OTHER CONFIGURATIONS}

There are numerous possible ATES well configurations in addition to the basic doublet. For larger sized systems, either a number of separate doublets, rows of doublets, concentric rings of injection and withdrawal wells, or other multiwell patterns can be utilized. Aquifer thermal energy storage systems can supply heat only, chill only, or combinations of heat and chill. In the latter case, several options exist. The heat and chill may be delivered in the same pipe (the two-pipe system), with cut-off dates designated for delivery of heat and chill, depending upon climate. Although this system minimizes capital costs, its lack of flexibility will probably make it commercially unattractive for many situations. Three-pipe systems can be employed that permit simultaneous delivery of both heat and chill with a common return pipe. Here a "triplet" well configuration would probably be used--a hot wel1, a cold well, and a mixed well. Another alternative is a four-pipe system with separate sets of doublets for the chill and heat storage cycles. In this case, the doublets need adequate space between one another, either horizontally or else vertically through the use of different aquifers. Heating and cooling can also be supplied via a two-pipe system that delivers only hot water if the buildings to be cooled are equipped with absorption chillers.

An entirely different concept of aquifer chill storage using the doublet system is under study by at least one researcher. (6) The standard ATES concept employs water as the storage medium and the aquifer as the containment vessel, with an attempt made to isolate the chilled water from the 
rest of the aquifer in a separate bubble. This second concept employs the aquifer as both the storage medium and the containment vessel, with the water used chiefly as the transport vehicle. The storage process involves a continuous cycling of chilled water from one well to the second through the aquifer (up to 10 times per storage period), with the result that the entire aquifer between the two wells is chilled. During recovery, the pumping is continuous in the opposite direction, and the water slowly removes the stored chill from the rock matrix. This concept appears favorable only for chill storage and for a restricted range of ground temperatures (bounded on the low side by ground water cold enough for direct cooling and on the high side by the temperature of the reject water from the air-conditioning system). The major advantage of this concept is that the temperature of the storage medium is already low, and therefore, only a very small change in temperature is required before a fluid suitable for direct cooling is obtained. "Apparent" aquifer efficiencies in excess of 100\% may be possible initially, since more "chill energy" may be withdrawn than was pumped in, due to the preexisting low temperatures of the aquifer. DESIGN CONSIDERATIONS

For the standard ATES system to operate properly, the warm and hot wells must be located far enough apart to prevent breakthrough. Breakthrough occurs when the temperature interfaces of the two storage bubbles meet or overlap, mixing the hot and warm waters and subsequently reducing the efficiency of the storage system. Optimum well separation is a function of aquifer parameters (such as thickness, porosity, transmissivity, etc.), maximum storage volume per cycle, and water temperature (since the shape of the storage bubble is a function of temperature). Well-spacing design is fairly straightforward for a single doublet system, although obtaining the data required could be difficult. Spacing designs can be complex, however, for systems employing numerous wells.

Selection of the aquifer is also a major design consideration requiring attention to many factors, including aquifer parameters, competing uses, and the characteristics of the energy to be stored. Aquifers are beds of 
permeable rock or unconsolidated sediments that contain and conduct water. Most are of sedimentary origin and are horizontal or dip slightly. They can range from depths of a meter or less to several kilometers, with thicknesses occurring in the same range. Fresh-water aquifers are generally found close to the surface; in general, the deeper the aquifer, the more saline it is likely to be. The aquifer employed must be thick enough and porous enough to provide suitable storage efficiencies, and its chemistry must be such that clogging or corrosion problems will be minimal.

During the selection process several tradeoffs may need to be made. Near-surface aquifers are preferable to reduce costs of wells and pumping energy. On the other hand, the temperature of the water to be stored may require a deep aquifer to provide the pressure necessary to keep it in a liquid phase, and it may be advisable to utilize a deep saline aquifer to avoid interference (or a public perception of interference) with potable water supplies. Generally, a confined aquifer (one overlain by an impervious layer) is desirable to prevent surface water's infiltrating the storage bubble. However, some research is being conducted on the use of near-surface unconfined aquifers. Numerous factors must be considered on a site-by-site basis to select the optimal aquifer. In a given location, of course, there may be only one aquifer with the potential for ATES development, and in this case, the decision will be one of go or no go.

System temperature is another design consideration. In general, for heating systems it is economically advantageous to operate the system at the highest possible temperature in order to maximize the energy content of the fluid, thereby minimizing capital expenditure. There are limits, however, imposed by the aquifer and by the energy resource. The aquifer limits system temperature in two ways: 1) the depth of the aquifer limits the pressure that can be exerted on the water, and hence, the temperature of the water itself, and 2) above a certain temperature, unacceptable dissolution of the aquifer matrix may take place. This latter constraint will vary from site to site because it depends on the composition and structure of the individual aquifer. If the aquifer does not set the upper limit of the 
storage temperature, the temperature of the heat energy source will do so because it is probably uneconomical to increase the temperature of the fluid prior to storage.

\section{AQUIFER THERMAL RECOVERY EFFICIENCY}

An aquifer's thermal recovery efficiency is one of the most important parameters in determining whether to use a specific aquifer in an ATES system, and it is probably the least predictable. The efficiency of the aquifer is a function of many variables. One of the most important is the amount of energy to be stored. Thermal energy is lost at the bubble surface, which grows as the square of the radius. The volume stored grows as the cube of the radius. Since the fraction of heat lost is a function of the ratio of the surface area to the volume, the larger the scale of injection, the smaller will be this ratio, and hence, the more efficient will be the system.

Another important factor is aquifer geometry. The aquifer must be thick enough to permit a compact storage bubble to form. A thin aquifer, for instance, would result in a long, flat bubble with a high surface-areato volume ratio, and a corresponding low efficiency.

Efficiency is also a function of storage temperature. The greater the temperature difference between the in-situ water and the stored water, the greater will be the heat transfer rate and the less will be the system efficiency. Another major factor in the determination of ATES aquifer efficiency is the natural rate of regional ground-water flow. With a zero flow rate, the injected hot water will remain stationary around the well and high recovery ratios will be experienced. Where a high rate of regional flow exists, essentially all of the energy will be swept "downstream" before the recovery cycle, and little energy will be recoverable unless the well pattern has been designed to account for the displacement.

The "apparent" aquifer thermal recovery efficiency is also a function of end-use flexibility (although the real thermal recovery efficiency is independent of any end use). Towards the latter part of the withdrawal 
operation, the water temperature will tend to drop, slowly at first, and then more quickly as the mixed water at the edge of the storage bubble is recovered. If system design is flexible enough to utilize this lower temperature water (e.g., a district heating system with oversized piping), the apparent aquifer efficiency will be greater than if the system must cease operation immediately when the water's temperature decreases a few degrees.

Computer models and experimental field data indicate that initial thermal recovery efficiencies may exceed $70 \%$ for confined aquifers of minimal regional flow with energy inputs of reasonable size. More heat will be lost to the aquifer during the early cycles of injection and recovery than during the latter cycles when the aquifer matrix and surrounding water are already warmed. Some investigators estimate that $80 \%$ to more than $90 \%$ efficiencies can be obtained after a number of cycles. (7)

HISTORICAL EXPERIENCE WITH ATES AND RELATED TECHNOLOGIES

For the design and operation of ATES systems a wealth of technical information and experience is available from related industries such as well drilling, petroleum production, and geothermal energy production. Injection of water into oil-bearing formations is a time-tested method for increasing the ultimate petroleum yield from a formation, and the petroleum industry is a tremendous source of experience on well-clogging and related injection problems. Similar information is available from a long history of fresh-water injection into coastal aquifers to prevent salt-water intrusion. The geothermal industry is an excellent source of expertise on hot corrosive brines and the effects of these solutions on well casings and equipment. Aquifers are presently used for storing fresh water in many parts of the nation, and the natural gas industry has been using aquifers for seasonal storage of natural gas for over 60 years.

There are several case histories of successful recovery of thermal energy stored in aquifers, but these have been incidental rather than planned. One such recovery operation is under way on Long Island, New York. There, continuous use of aquifer water for cooling purposes over decades has raised 
the temperature of the aquifer $17^{\circ} \mathrm{C}\left(30^{\circ} \mathrm{F}\right)$ in some areas, such that some buildings are now employing the aquifer water for heating. A similar situation is being exploited by the City Hall at Fresno, California. ( 8 )

Recent disclosures show that the People's Republic of China has been injecting winter-chilled water into aquifers beneath the City of Shanghai for a decade, with withdrawal for summer air conditioning. Cooling was initially a secondary use of the injection program, as the initial aim was to combat the severe subsidence plaguing the city. Now cooling is a major incentive for the pumping program, and there is some storage and recovery of heat. (9)

Finally, numerous ATES-related storage experiments are under way, supported by PNL's STES Program and by independent researchers. Preliminary results indicate that ATES systems are indeed technically feasible. 


\section{TECHNICAL FEASIBILITY}

While one major advantage of aquifer thermal energy storage is its almost exclusive reliance upon existing technology, this does not mean that implementation of ATES is without technical problems. The very simplest applications are straightforward, but as ATES technology is applied to ever more varying situations, more and more technical problems will need to be solved. An examination of these potential problems can best be made by looking at each of the four components of the ATES system (energy collection, storage, transport, and end use) separately.

ENERGY COLLECTION CONSIDERATIONS

The purpose of the energy collection component of the system is to transfer heat or chill from the source to the storage fluid. The key is to extract the maximum amount of heat/chill from the energy source at the desired storage input temperature. Such a goal is typical in the design of any heat exchanger, and the design techniques for this are well established. For most conditions anticipated it should be possible to use standard heat exchanger designs fabricated from standard materials. However, some of the most attractive waste heat sources are in the form of extremely hot, potentially corrosive or erosive gases. The stack exhaust gas from steel and aluminum plants is a prime example of such an energy source. The magnitude and high temperature of the rejected energy in these plants make recovery highly desirable from the standpoints of resource conservation and reduction in thermal pollution, but the limits of available materials for the heat exchanger seriously limit recovery capability. If the ATES technology is to reach its full potential, materials science will have to advance to enable recovery of energy from harsh conditions such as these. Fortunately, there are other economic incentives for development of such capabilities beyond ATES, and the ATES Program will no doubt benefit from industry and government-financed materials development programs. Meanwhile, the lack of such materials does not eliminate waste heat utilization for ATES feasibility, but merely limits it to more easily handled waste heat sources, of which there are many. 
A second consideration in the collection of waste heat for ATES systems is that very often waste heat temperatures are maintained because of specific operational requirements. A lowering of the exit temperatures of the waste stream at intermediate points within the plant may lead to problems with plugging, corrosion, or the undesirable precipitation of substances in the heat exchangers or waste disposal systems. Thus recovery of reject heat from some plants may involve expensive redesign of portions of the existing plant, or it may involve relatively expensive add-on heat exchanger equipment to collect the energy after it has already left the physical structure of the plant.

The design of systems to collect power plant waste heat may present problems in a few cases. Many urban stations are located in congested areas where space limitations may prevent the recovery of waste heat. Furthermore, the mechanical features of steam and electric generating facilities differ according to the age, construction techniques, and other characteristics of plants. In some cases, the condenser cooling water discharge may be inaccessible, or else evaporative or dry cooling systems may be used in lieu of circulated water. Turbines may be of such design that extraction of steam is impracticable. Because of these inherent differences between plants, it is likely that no summary judgments can be made about the feasibility of converting power plants to waste heat sources. Rather, each plant will have to be examined in detail.

A final area of potential technical difficulty is the collection of "free chill" from the atmosphere. Where system conditions permit oxygenation of ground water, there is probably minimal difficulty in obtaining chill from the air because simple cooling and/or spray ponds can be used. Where aquifer conditions mandate that ground water be strictly isolated from the atmosphere, however, closed systems such as dry or wet cooling towers with an intermediate heat exchanger may be required. In general, cooling tower technology does not deal with the cooling of liquids at or near the freezing point, but rather with the cooling of hot liquids to make them suitable for discharge to the environment. The potential problem that exists when 
handling $2^{\circ} \mathrm{C}\left(35^{\circ}\right)$ water is that of system freeze up. While this is probably not a difficult technical problem (since chilling is a function of temperature only, and not of cooling load), new control systems will be needed for the chilling process.

\section{STORAGE CONSIDERATIONS}

There are three potential problem areas in the ATES storage function: definition and selection of suitable aquifers, well design, and well plugging difficulties.

The ideal aquifer for ATES use is moderately thick (100 ft), bounded both above and below by horizontal layers of very low permeability. It is homogeneous, composed of uniformly fine particles $(1 \mathrm{~mm})$, and has a high porosity, moderate horizontal permeability, and low vertical permeability. It is characterized by a zero regional flow, and its chemistry is unaffected by oxygenation of the injected water, high temperatures, or other factors. In such an aquifer, the injected water would lie in a cylindrical pattern centered on the well. (The optimal storage bubble shape is a sphere, with its minimal surface-to-volume ratio. Realistically, the optimal attainable geometry is probably a cylinder, with its height equal to its diameter.) At recovery, a maximum yield would be available, since the water would flow uniformly back toward the center as the well was pumped. Since there are few ideal aquifers, some major questions appropriate to ATES become: 1) At what point do aquifer characteristics become so poor that the aquifer is unsuitable? 2) How do we cost-effectively determine the attributes of a specific aquifer (aside from the actual in-the-field tests)? 3) How can we "work" the aquifer to better its characteristics and make it amenable to ATES storage?

With regard to the first question, many characteristics can make an aquifer unsuitable for energy storage. An aquifer may be too thin, causing a large area/volume ratio. Consequently, net heat loss increase and efficiency drops. Or the regional flow may be excessive, in which case the bubble of stored energy flows downstream and can pollute the ground water of other users, allowing the ATES operator to recover little of his injected 
energy. The aquifer may have a permeability that varies with direction, causing the water to be stored in asymetrical fashion. Vertical faults may close off the aquifer in one or more directions, or they may interconnect different aquifers. While the present state of technology can define the ideal aquifer, the state is not so advanced that it can look at variations from the ideal profile and determine suitability. Suitability $c$ an be equated in one sense to recovery efficiency. If the ideal aquifer (with an initial recovery efficiency of $70-80 \%$ over 6 months) is reduced from $100 \mathrm{ft}$ in thickness to $40 \mathrm{ft}$ in thickness, what is the effect on recovery efficiency? What if there is a regional flow of one meter per day? One meter per week? What about the existence of many clay lenses? Simulation modeling is being widely undertaken to answer these questions, but much developmental work remains.

Even if the answers to the above questions were known, the suitability of a particular aquifer could be assessed only if the descriptive data were available about the aquifer. Information on the subsurface environment is difficult and costly to obtain. To determine a number of the aquifer characteristics (such as anisotropic conditions), requires extensive instrumentation, many wells, and considerable time and effort. Many ATES developments may be marginally cost effective, and the time and money required for aquifer evaluation could make these developments economically unattractive. Creation of practical guidelines for determining aquifer suitability may well be the key to widespread ATES development because the main obstacle to such development will probably be uncertainty about aquifers. A major thrust of the ATES development program, then, needs to be an in-depth evaluation of aquifer suitability: What characteristics are most desirable? What are the limits of these characteristics for acceptability? How can we predict from existing well data which aquifers will possess which characteristics? Which additional data need to be obtained? What is the most cost-effective way to obtain that data?

It appears that if an aquifer is marginally unsuitable for one reason or another, it might be possible to modify the aquifer to enhance its attractiveness. One of the most undesirable aquifer attributes is a large regional 
flow rate. There are, however, several means of neutralizing this regional flow in the near environment so as to effectively improve the efficiency of the aquifer. If the aquifer is sufficiently shallow, an actual physical curtain can be fabricated to act as a dam and hold the water in. A more likely method for most situations would be to drill a series of wells around the proposed storage area, with the upstream wells being pumped into the downstream wells, creating within the well area an equipotential area, or zero hydraulic gradient. Aquifer flow would be neutralized and maximum energy could be recovered. Another approach to aquifer modification might include use of several thin aquifers to simulate a single aquifer in a sandwich arrangement.

The second potential problem area of storage technology is well design, with one of the major problems being corrosion and scaling of the well casing and downhole pumps. This problem is especially difficult when using saline aquifers (which may often be advisable due to the competition for use of fresh-water aquifers) and for very high-temperature energy streams. Design and construction of these wells and pumping equipment can benefit greatly from the experience and research efforts of the developing geothermal industry, and from the $0 i 1$, gas, and water we 11 industries. If the geothermal industry is successful in developing effective corrosion and scaling control methods, aquifers initially thought unsuitable for ATES systems may become usable. Meanwhile, problems may be decreased by promotion of lower-temperature ATES systems and by judicious selection of aquifers.

There are, additionally, well design problems unique to the ATES technology. One of these is thermal cycling of the well system. Whereas a geothermal we 11 operates at a fairly constant temperature, an ATES we 11 may see temperature variations between injection and retrieval cycles, and large changes in temperatures during nonoperational periods. The resultant thermal1y-induced stress cycling of the well-casing may cause failure of the we11-casing cement, which could result in leakage of the hot fluid into formations being used for water supplies. One answer is continuous operation: hot fluids may need to be circulated up and down even when the 
well is not in the injection or retrieval operations. Of course, this will result in cost penalties. Other options include the development of more resilient casing and grouting materials which can better handle the thermally-induced stresses.

Another problem specific to ATES system design results from the two-way nature of the storage wells. Each well must be usable as both a production and injection well with minimal changeover effort. Submersible pumps are available for use with production wells, but present designs do not permit backflow such as is required during injection. Injection into the well annulus, thus bypassing the downhole pump, would permit uncontrolled cascading of the injected fluid. This could result in flashing or air entrainment, both of which could lead to plugging of the aquifer formation. The current technological solution is a separate injection tube which bypasses the downhole pump and which is designed to prevent cascading; but this is expensive. The unavailability of a reversible downhole pump is probably not due to technical difficulties, but rather to the fact that previously there has been no demand for such equipment. Perhaps with increasing demand for ATES, such equipment will be forthcoming from pump manufacturers; otherwise, developmental assistance may be required by the ATES Program.

A final technical difficulty is that of maintaining permeability of the aquifer near the injection we11. Plugging of the aquifer may occur for many reasons, including: entrainment of gas bubbles, plugging of the pores with fine particulates in the water, biofouling from algae or bacteria growth, or reactions of the mineral matrix to the injected water. We11plugging is a common occurrence in injection wells, as the experiences of the $0 i 1$ and gas industries can attest. Generally, suitable maintenance procedures (such as backflushing and chemical treatment) will return most of the permeability. More work needs to be done in this area, with emphasis placed upon chemical reactions that occur within the aquifer as a result of heating the aquifer water. 
TRANSPORT AND DISTRIBUTION CONSIDERATIONS

There is a vast amount of experience with the transport of fluids over long distances, and there appear to be no major technical difficulties inherent in this technology. The major obstacle is expense: the costs of pipes, insulation, construction, and right-of-way acquisition severely limit economically-feasible transport distances.

These costs increase significantly when district heating is the intended use of the stored energy. Since labor cost is the dominant component of pipeline construction (about $75 \%$, according to one estimate), (10) development of new construction techniques and equipment should be a major objective of a national effort to implement district heating systems. One possible approach is development of a mechanical mole to be used in developed areas. Another is improvement of plastic piping. Its low purchase price, high durability, ease of joining, and the capability of emplacing in longer sections could reduce the overall cost of piping and increase the feasible transport distance for district heating systems. Development of cheaper and more durable forms of pipeline insulation also would be of great benefit.

One technical problem is the difficulty in retrofitting existing district heating systems, which are almost exclusively steam distribution systems, to more modern hot water systems. It is generally conceded that hot water systems are superior to steam systems for many reasons. These include better temperature control, faster response to load changes, reduced insulation requirements, easier installation of pipelines, the requirement of fewer specialties, and the elimination of air, thereby reducing corrosion and maintenance. The retrofitting process is not trivial. Complete replacement of the existing system may be required in many cases; in others a steam-to-water heat exchanger may suffice.

END-USE CONSIDERATIONS

As is the case with transport considerations, the major difficulties concerned with end use are economic, and again, district heating systems greatly magnify these problems. The retrofitting of existing buildings to implement district heating is costly, and development of inexpensive retrofit 
technology would greatly enhance the prospects for district heating. Furthermore, given the number of low-temperature heat sources potentially available for district heating, development of cost-effective heating systems that could use these resources would be beneficial. Absorption chillers look promising as a means of using hot water to cool individual residences. These chillers, however, generally require hotter water than do space heaters, and they operate with a smaller temperature drop than do the heaters. More developmental work is needed with these units to improve their cost effectiveness. 
ENV IRONMENTAL CONS IDERAT IONS

In general, the acceptability of a new technology from an environmental viewpoint appears to depend on two criteria: 1) the sum total of positive effects (including environmental, economic, and social effects) must outweigh the sum of negative effects upon the environment, and 2) no one negative environmental effect may be intolerable. If these are the criteria applied to the ATES technology as a whole and to individual ATES developments on a case-by-case basis, then there probably will be little opposition to ATES implementation on environmental grounds.

A preliminary assessment of the likely consequences of large-scale implementation of the ATES technology indicates a net positive effect upon the quality of the environment, primarily due to a reduced national demand for fossil fuels and the resultant reduction in pollution from the extraction, refining, and combustion of those fuels. The negative effects, should they occur, are predominantly site-specific and are associated with the underground storage of hot water. None of these appears serious enough to threaten the feasibility of ATES development.

ENVIRONMENTAL ADVANTAGES

Widespread implementation of the ATES technology in conjunction with cogeneration, waste heat recovery, and the collection of solar energy can significantly reduce the demand for fossil fuels. Some estimate the long-term substitution of primary energy sources to be as high as $10 \%$. (11) This reduction in demand can be translated directly into a reduction in pollutants emitted into the environment and a reduction in the capital investment needed to treat that pollution. Not only is the combustion of displaced coal, oil, and gas eliminated, but the extraction, refining, and transport of that displaced fuel is also eliminated, and these are activities that heavily tax the environment.

In addition to decreasing contaminant emissions, ATES development has the potential for widespread reduction in thermal pollution of the atmosphere and surface-water bodies. Thermal power plants are grossly inefficient 
from the viewpoint of total energy utilization. About two-thirds of the energy content of the fuel consumed is delivered to exhaust gases and cooling water and then into the environment in the form of thermal pollution. Cogeneration, made practicable by seasonal storage, can render much of this waste heat usable. Thermal pollution is thus mitigated, and capital investment in thermal pollution control equipment can be reduced. These same benefits will accrue through the capture of industrial waste heat.

These reductions in contaminant and thermal pollution will be significant from an overall viewpoint, but they will be even more important on a local basis. Because source/load considerations generally restrict development to densely populated or industrially intense locations, the savings in pollution will occur where pollution loads are already highest and reductions are most needed. Furthermore, district heating systems, made more attractive by the availability of ATES technology, will result in eliminating combustion of coal, oil, and natural gas in the individual residence, where pollution control is minimal. Space heating pollution will be centrally located, where up-to-date technology can minimize that pollution.

POTENTIAL ENVIRONMENTAL PROBLEMS

The most likely negative environmental impact foreseen for ATES developments is ground-water thermal pollution at the storage site. There are numerous other potential environmental problems, but these can be avoided through proper engineering design, careful operation, and continuous monitoring of the individual ATES developments.

The intent of the ATES storage process is to heat the original ground water so that a large amount of thermal energy can be stored at depth and recovered later. As a side effect, the heating of the rock matrix and the immediate surrounding water envelope is unavoidable, and it is desirable in an operational sense because it serves to increase storage efficiency over time. (ATES is actually a dual-media system: both water and rock store the heat. Much of the energy stored in the rock matrix is recovered when cooler water at the periphery of the storage bubble is drawn back through the matrix.) The key to maintaining an environmentally acceptable operation 
is to control the thermal energy so that: 1) it is not detrimental to the immediate site and 2) it does not migrate to adjacent areas where it could interfere with ground-water use by others. The former objective can be managed through careful engineering. The latter can be ensured in several ways, including:

- selection of an aquifer with minimal or nonexistent regional flow

- elimination of regional flow (if it exists) through judicious well placement and pumping routines

- selection of a deep and/or brackish aquifer that is not used as a source of potable water

- location of the storage wells "downstream" from other users with respect to regional flow

- isolation of the storage wells at an adequate distance from all other users

- restriction of water temperatures to ranges acceptable for safety and environmental protection.

It is important to remember that the size of the storage bubble generated by a fairly large ATES installation has a radius of only several hundred feet. ${ }^{(3)}$ The ownership of surface land beyond the limits of the bubble, in conjunction with the above aquifer selection criteria, should minimize the potential problem of interference with the water rights of others, at least from the standpoint of their finding hot water in their wells. It is likely, however, that after 20 to 30 years of 1 arge-scale operation the temperature of the aquifer in the general area of the ATES development will have been raised several degrees or more. This has been the experience in areas where there has been widespread use of well water for cooling purposes with re-injection. The implications of this are unclear. Some effects would be positive, such as the reduction in the need to heat water for sanitary purposes, the availability of warm water for beneficial use in agriculture, and even the possibility of space heating on a small scale. Negative effects would begin to appear as the water temperature rose higher, such as the 
need to cool the water before consumption. Undoubtedly, the potential problem is one of scale. If the temperature is changed only a few degrees, or even a few tens of degrees, there might be no problem. City water supply temperatures change by this much within a year. If, however, the water actually runs hot, then the environmental implications would be more serious. Work needs to be done to quantify this potential problem before large-scale implementation in areas that depend heavily upon ground water for residential and other uses. In any case, major changes in water temperature are likely to be extremely localized.

A much more serious, but less likely problem, is chemical contamination of the aquifer. This could occur in several ways, including direct injection of noxious substances, corrosion of system components, mixing of different aquifers, or dissolution of toxic substances within the aquifer matrix (as a result of the change in solubility accompanying the change in temperature). Each of these potential pollution routes can be eliminated through proper engineering and careful monitoring of the ATES operation. Injection of noxious substances can be prevented by the careful isolation of aquifer water in closed-system heat exchangers; corrosion products can be excluded through the proper design of those systems. The isolation of aquifers from one another is not a difficult engineering problem and is generally required for all water wells. The change in solubility of minerals with in the aquifer presents a more difficult problem, both from an operational and an environmental viewpoint. There is little that can be done to prevent dissolution given a specific set of circumstances. The key is to be able to predict what will happen within the aquifer when the hot water is pumped into it, so that if necessary, temperatures can be reduced or a different aquifer can be selected. Laboratory tests of aquifer matrix at each potential site can provide this information.

OTHER SUBSURFACE CONCERNS

Several hydrology-related issues have been raised as possible environmental problems, including changes in ground-water availability, in regional flow, and in permeability of the aquifer. On closer inspection, these appear to have little chance of occurring. 
One of the cornerstones of the ATES technology that it uses but does not consume water. That is, water is pumped out of the aquifer, heated or cooled, and then returned directly to that same aquifer a short distance away. In general, there is no provision for surface storage except for that needed to fill the pipeline and heat exchanger, and possibly for small surface cooling ponds for collection of winter chill. This use should not affect the level of the water table to any great extent, and hence the availability of ground water to other users should not be affected.

Changes in regional flow are caused by changes in the gradient, which reflect changes in the relative heights of the water table. Since ATES is a nonconsumptive use, there will be no gross changes in the water table, and thus there should be no significant change in regional flow beyond the immediate neighborhood of the ATES wells.

ATES will probably affect the permeability of the aquifer in the immediate region of the injection wells. This is a common experience with almost all injection wells, but it occurs only in the immediate neighborhood of the wells and the phenomenon does not extend into the aquifer. The problem is really an operational one: if the well's ability to accept injected water is seriously reduced, then new wells will have to be drilled or else the ATES development will have to be abandoned. It is obvious, then, that in contrast to many energy technologies, efficient operation and the economic feasibility of ATES really depend upon minimal disturbance to the surrounding environment. Protection of the subsurface environment will be largely selfpolicing.

Several other environmental concerns have been identified in conjunction with ATES development. One of these is subsidence and/or regional uplift. Another is a stimulation of seismic activity. Significant subsidence occurs only with gross withdrawal of ground water without recharge; uplift occurs with an overcharge of water to the aquifer. Neither of these can readily be foreseen for ATES because it does not consume water. Increased seismicity due to water injection is a rare and unlikely event thought to be caused by 
high-pressure injection of fluid into low-permeability media or by lubrication of stressed fault planes at depth. Since cost-effective implementation of ATES can be achieved only by using relatively shallow aquifers with moderate to high permeabilities, it is unlikely that ATES implementation will cause seismic occurrences.

There will, of course, be construction-related negative effects upon the environment, as is typical of any large-scale construction project. These will be site-specific and temporary. The potential magnitude and significance of these effects will depend entirely upon site selection, construction techniques, and system operation and management. These will probably be minimal compared to other energy generation technologies.

A final area of concern exists in conjunction with district heating systems, a primary use of the ATES technology. The pumping of hot water into residential neighborhoods for the purpose of space heating will be a new concept for most of the nation, and the potential for rupture and injury exists, although it is very small. In Europe, where district heating is commonplace, no serious problems have been experienced.

\section{CONSIDERATIONS FOR ENVIRONMENTAL ASSESSMENT AND MONITORING}

Although no obviously disruptive environmental concerns appear to exist, it is important that a comprehensive analysis of the concept and of each individual proposed ATES development be undertaken and that monitoring activities be made a part of ATES operations at each site. One reason is that ground water is a fragile and extensively used resource; another is that environmental controversy results from the perceptions of the public, of industry, and of concerned government agencies.

The ground-water resource is enormous (97\% of the nation's fresh water is underground), (12) and the nation's dependence upon it is 1 arge (22\% of the total fresh water consumed comes from wells), (13) but it is also fragile. Unlike a surface stream, which is subject to fairly quick self-cleansing and is approachable for large-scale human clean-up activities, an aquifer, once contaminated, is likely to remain so for long periods. Given the 
nation's reliance upon aquifers, any contamination of water supplies originating from the aquifer could create significant adverse impacts with not only health, but also legal, political, social, and economic implications.

Another reason for careful analysis of the environmental effects of the ATES technology is that acceptability of the concept will depend upon the impacts as perceived by the affected individuals, companies, and government agencies. These perceptions are derived from experience with similar technologies and from the relevant technical data generated for the evaluation at hand. Where data are not available, many people will assume worstcase conditions, especially when they perceive that their drinking water may be affected. Thus it is important for the introduction of a new technology such as aquifer thermal energy storage that background work be performed to present a realistic picture of the actual situation, including identification of: 1) any potential environmental impacts, 2) their probable magnitudes, 3) the probabilities of occurrence, 4) strategies for prevention, 5) environment-monitoring procedures, and 6) the effectiveness of possible mitigating/recovery actions. Early effort in this area can avert costly delays in implementation. In addition, such research will serve the formal requirements of NEPA and other environmental legislation. 


\section{RESOURCE AVAILABILITY: AQUIFERS}

Aquifer thermal energy storage developments, by definition, will be limited to sites where suitable aquifers exist. There seem to be no serious geologic constraints to ATES development since about two-thirds of the nation is underlain by aquifers. Those areas not underlain by aquifers are typically nonindustrial and lightly populated. Major cities, and, consequently, the sites most desirable for ATES implementation, tend to be 10cated near productive aquifers. Cities are usually founded on major rivers, and these rivers are generally paralleled by long, narrow alluvial aquifers which form the valley floor in the stream valley proper. Additional alluvial deposits are also generally found as terraces above the valley floor, steplike relicts of the time when the stream flowed at a higher elevation. Those cities not located on major surface waterways can usually be depended upon to have extensive aquifer systems beneath them which they use for water supply.

Much information is available on aquifers, both on a national level and on more detailed local levels. Initial estimates on the probability of suitable aquifer occurrence at a particular site should be available through literature reviews, without the need for investigatory field work. To obtain more detailed information on the relevant characteristics of the aquifer, field work will generally be required. This is especially true if ATES is considering the use of deeper (perhaps more saline) water than is used for potable water supplies.

\section{AQUIFER SUITABILITY}

Suitable aquifers may occur as a wide range of lithologies, the most common of which are: 1) relatively recent deposits of unconsolidated sand and gravel, 2) consolidated conglomerates and sandstones, 3) limestones and dolomites with well-developed secondary porosity from fractures and solution passes, and 4) fractured volcanics. Unconsolidated aquifers are the most likely candidates for ATES development due to their high storage capacity, excellent transmissivity, and shallow depth. However, other types 
of aquifers may prove suitable for regions where unconsolidated aquifers do not exist or for regions where competing uses, regional flow rates, or other factors may make use of the unconsolidated aquifer inadvisable.

Many areas of the nation have overused their ground-water resources and depleted the supply. Consequently, in these areas limits may be imposed on future withdrawal to protect the resource. Although ATES is a nonconsumptive use, political and/or legal impediments may result from ground-water depletion and subsequent remedial actions.

The ideal aquifer for ATES development is characterized by several attributes:

- The aquifer should be of suitable thickness; generally, about $100 \mathrm{ft}$ is suggested for an ATES development of moderate size. If the aquifer is too thin for the scale of storage, then the storage bubble will take on a tabular configuration, with the ratio of surface area to volume increasing and aquifer efficiency decreasing.

- The aquifer should be isotropic horizontally. That is, the permeability should be equal in all horizontal directions to ensure circular symmetry about the well and maximum efficiency.

- The natural rate of regional flow should be insignificant in order to maintain the stored thermal energy in a symmetric pattern around the injection/withdrawal wells. It may be possible to utilize an aquifer with a larger rate of flow, if recovery wells are situated "downstream" of injection wells or if the natural rate of flow can be neutralized by well-pumping procedures.

- Use of a confined aquifer is preferable. A confined aquifer is bounded both below and above by layers of very low permeability (generally clay), isolating the sandwiched aquifer from other aquifers and from surface-water intrusion. An ATES development in an unconfined aquifer is likely to display a reduced efficiency because of dilution of the storage bubble by surface (or aquifer) waters of more moderate temperature. Use of a near-surface unconfined aquifer may be feasible, however, if the "cost" of reduced efficiency can be compensated for by reduced well-drilling and pumping costs. 
- The confining layers should be of adequate strength and thickness to withstand the injection pressure without rupturing.

- The aquifer/confining layer system must not be susceptible to fatiguing due to cycling of the working fluid, nor susceptible to dissolution or weakening due to the temperature of the stored water.

- The aquifer should be free of structural irregularities such as vertical faults and lenses of clays or other impermeable substances.

\section{AQUIFER OCCURRENCE}

Hydrologic conditions differ greatly across the United States. Most highly populated areas are located near major aquifer systems, although there may be local areas not underlain by aquifers suitable to ATES development. Geologists generally divide the contiguous 48 states into 10 groundwater regions based upon type of aquifer. These regions are shown in Figure 2 and are briefly summarized below. (12)

- Western Mountain Ranges: This region includes the Rocky Mountains, the Cascade Range, the Sierra Nevada, and the Northern Coast Ranges. These mountain ranges are generally composed of formations unfavorable for the occurrence of ground water, although isolated alluvial deposits may provide suitable characteristics for ATES development. In general, these areas are lightly populated and nonindustrial.

- Alluvial Basins: This region consists of valleys and basins that surround or are surrounded by mountain ranges. These are filled with unconsolidated materials, some places more than a thousand feet thick. Ground water is widely used and generally plentiful despite depletion in some limited areas.

- Columbia Lava Plateau: The Columbia Lava Plateau is underlain chiefly by basalt lava many hundreds to thousands of feet thick. Suitability to ATES development is highly variable, depending upon the permeability of the strata. In some places the lava is reduced to highly permeable and highly porous rubble; in others there is no ground-water resource. 


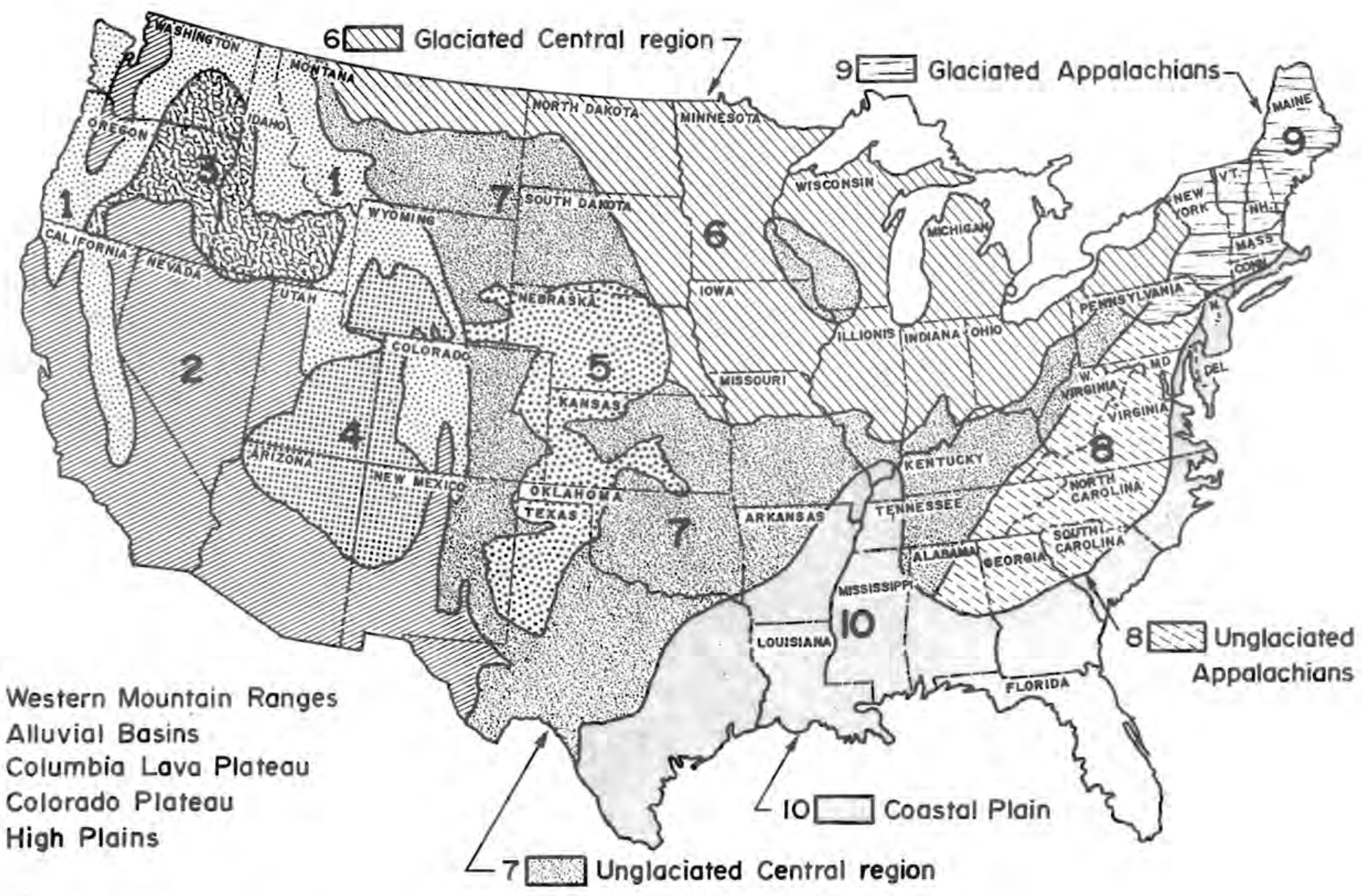

FIGURE 2. Ten Major Ground-Water Regions of the United States
Excepting Alaska and Hawij(12) 
- Colorado Plateau: This region has only very limited amounts of ground water. It is sparsely populated, however, and so the demand for ATES development would be minimal.

- High Plains: In general, this area is a large alluvial apron characterized by thick water-bearing deposits suitable for ATES development. Ground-water depletion is a major problem in some regions.

- Glaciated Central Low Land: The mantle of glacial drift characterizing this region contains many highly-productive aquifers, and the bedrock below is also productive in many areas. Problems with water depletion are not widespread although there are a few localized shortages in industrialized areas.

- Unglaciated Central Region: This region is characterized by only a moderate ground-water resource except along river basins, where aquifers of substantial width and thickness can be found.

- Unglaciated Appalachians: This area will require systematic investigation to define the sites suitable for ATES since the ground-water resource is highly variable throughout. Generally, the best prospects are the sand and gravel beds in the alluvial material of the flood plains of perennial streams.

- Glaciated Appalachians: There are some good bedrock aquifers, but the best are sand and gravel outwashes of glacial origin in the floors of existing and buried valleys. Many of these valley deposits are of limited thickness, and so aquifers may need to be selected carefully.

- Atlantic and Gulf Coast Plain: This region is abundantly endowed with good aquifers and plentiful ground water.

Alaska's ground-water availability is complicated by several factors, including permafrost. Aquifer production is poor in the more heavily populated southeastern coastal area. Hawai i is built upon a permeable basalt lava. About $40 \%$ of its water supply is furnished by ground water. (12) 


\section{RESOURCE AVAILABILITY: ENERGY SOURCES}

An extremely wide range of potential energy sources exists for ATES because the seasonal storage system, by its nature, is extremely flexible as to the amounts and types of energy it can accept. Timing of input flows of energy, the consistency (or inconsistency) of those flows, the quantities involved, and even the temperatures to some extent can be leveled out over time to supply energy tailored to meet the demands of the eventual user. This levelizing enables the ATES system to utilize those energy sources which may be seasonal, which may consist of numerous relatively short intensive energy spikes, which may have widely differing temperatures and volumes over time, and which might be undependable. Seasonal energy storage in aquifers can make otherwise impractical energy sources major factors in the nation's overall energy picture.

The one restriction an ATES system imposes on its energy source is that it be located relatively close to the end user. Although oil and gas can be economically transported over thousands of miles, the economic limit for hot water systems is probably 100 miles or less, depending upon the temperature of the fluid, the magnitude of the flow, and the load factor of the system. This is due to the low energy content of the fluid: fuel oil contains on the order of 100 times more energy than an equal volume of hot water. This constraint is actually less onerous than it seems, since most potential sources and uses are collocated in areas of relatively dense population. One major source potentially isolated from prospective users is the nuclear power plant. While these plants produce tremendous amounts of waste heat, future plants will typically be sited away from heavily-populated areas.

\section{ENERGY SOURCES}

Potential energy sources can conveniently be partitioned into three major categories: climate-dependent sources, byproduct sources, and dedicated sources. Climate-dependent sources can further be broken down into solar heat and winter chill; byproduct sources into industrial waste heat, cogeneration, and heating/cooling reject fluids; and dedicated sources into a number of types, including refuse incineration, heat-only nuclear plants and others. 
Solar energy is an extremely attractive energy source because it is nonpolluting, ubiquitous, and renewable. Unfortunately, it is also diffuse and unreliable, and mostly available in the summer when it is not needed for its most logical use, space heating. Generally, a 100\% backup capability must be installed with systems designed to use solar energy directly, greatly increasing the cost of solar space heating. Thus a low-cost seasonal storage system in which heat collected in the summer can be used in the winter, thereby obviating auxiliary backup and reducing the associated problems of load management, would be of great benefit. Furthermore, by improving the utilization of available solar input over the full year, seasonal storage reduces collector area requirements. The resultant savings in hardware costs represent a major economic benefit of seasonal storage.

The utilization of winter chill for summer air conditioning presents a similar supply/demand matching problem. Chill is available in three major forms: chilled air, cold water from surface water bodies, and snowfall. Chill utilization is somewhat geographically limited, however, since regions with high air conditioning loads typically have mild winters, whereas areas with readily available winter chill typically have mild summers. Fortunately, there are many exceptions to this situation, and the utilization of winter chill has been the subject of widespread investigation for several years. Furthermore, for very large structures with considerable internal heat sources (such as office buildings and factories), the air conditioning load is somewhat independent of external temperature. Air conditioning may even be required year round. Utilization of winter chill is especially attractive for these situations.

The second category, byproduct heat sources, is perhaps the most economically attractive energy source for ATES systems since the heat provided by these sources is generally more concentrated. Industrial waste heat is found in three forms: hot exhaust gases, hot liquid waste streams, and radiant heat from the cooling of hot substances such as metal ingots, masonry bricks and food products. The key descriptor for industrial waste heat is "variability." Waste heat from the production of steel can reach $1600^{\circ} \mathrm{C}\left(3000^{\circ} \mathrm{F}\right)$ while waste water from food process plants may average only 
$60^{\circ} \mathrm{C}\left(140^{\circ} \mathrm{F}\right)$. Moreover, a given industrial plant may have several waste heat sources at different temperatures. Hot gas from the kiln used to make cement may vary from $370-800^{\circ} \mathrm{C}\left(700-1500^{\circ} \mathrm{F}\right)$; hot gas from the clinker cooler in the same cement plant will be from $175-230^{\circ} \mathrm{C}\left(350-450^{\circ} \mathrm{F}\right)$. The total energy available for storage can also vary greatly. A primary aluminum plant produces on the order of 55 million Btu's per ton of aluminum. The waste heat from a typical plant could supply the hot water and heating needs of 12,000 single family dwellings, thus saving the equivalent of 250,000 barrels of oil per year. (15) on the other hand, many industries are characterized by small plants with relatively small waste heat output. However, if these plants were clustered together in an industrial park, for example, the levelizing function of seasonal storage could make energy recovery economically attractive.

Even within a single industry, or within a single company, there is widespread variation in age, condition, capacity, and design of individual plants, and in the system processes employed by those plants. The variety of possible waste energy sources makes it impossible to define or discuss a "typical" source. Rather, feasibility investigations will have to be made on a case-by-case basis.

A second major byproduct energy source is cogeneration. Cogeneration is the simultaneous joint production of heat and electricity at a single plant. In a conventional power generation plant (that is, with no cogeneration) only about one-third of the energy content of the fuel is converted to electricity; the remaining two-thirds is rejected as stack exhaust and in the cooling water. The warmed cooling water is too cold (about $35^{\circ} \mathrm{C}$ ) $\left(100^{\circ} \mathrm{F}\right)$ to be useful for anything except limited special applications such as warmed irrigation water or aquaculture. In a cogeneration plant, however, the efficiency of the generating turbines is reduced a small amount, with the result that the cooling stream temperature is raised to a level appropriate for many uses, including process heat and space heating. Up to ten times as much useful heat energy is recovered compared to the electrical energy sacrificed in the generation process. A further bonus is that cooling towers are no longer required, and thermal pollution is minimized. In 
the past, cogeneration's benefits have been realized only on a very limited basis chiefly because it made operational and economic sense only when there was a continuous and immediate use for captured heat. With seasonal storage, however, widespread implementation of the cogeneration concept is more feasible. Even after storage and distribution losses inherent in the aquifer storage process are accounted for, cogeneration results in an impressive gain in fuel efficiency.

The third type of byproduct energy consists of heating/cooling reject fluids from space heating and cooling, typically the outlet water from a water source heat pump. Warmed water from summer air conditioning can be stored until winter, retrieved, and used by the same heat pump for winter heating. Likewise, the reject cool water from the winter heating can be stored and recovered for summer cooling by the same heat pump. The attractiveness of this doublet system is its simplicity and adaptability: it can be used on any scale from a small single user to an entire community system. And it requires little more capital investment than the original heat pump-related equipment.

The third category consists of dedicated energy sources. The key feature of these sources, which aligns them with seasonal storage rather than with direct energy supply to the user, is that they must (for one reason or another) be operated continuously. One prime example of this type of energy source is a municipal refuse incineration plant. The generation of steam in a refuse incinerator cannot reasonably be varied to meet load conditions. In cases where energy supply exceeds demand, expensive thermal pollution control equipment must be installed and energy must be wasted. Where demand exceeds supply, the plant must be equipped with an auxiliary fuel-firing system to meet contracted demand. Furthermore, garbage generation is continuous, and an alternative disposal system must be sought if the incineration plant needs to be shut down because there is no need for summertime district heating. Seasonal storage is ideal for such a situation, and it can turn an expensive disposal problem into a revenue-generating activity.

Another example of a dedicated energy source is a heat-only nuclear reactor. As the conversion efficiency in these units is about $100 \%$, heat 
costs should be less than the cost of electricity. While there is no apparent U.S. activity in this research area, some European countries have shown considerable interest. The fact that the proposed systems are low pressure and low temperature, simple in design, and located underground might enable locating the reactors close to population centers. This would overcome the long-transport problems inherent in using remotely sited nuclear plants to supply hot water for space and process heating. ENERGY SUPPLY

The use of seasonal thermal energy storage could have a major impact on the rate of consumption of primary fossil fuels. The capture potential of solar heat and winter chill is unlimited, with implementation dependent only upon the economics of individual situations. Recovery of waste heat from industrial processes also has great potential. One estimate is that by 1985 the equivalent of 11.8 million barrels of $0 i 1$ annually could be displaced by the energy savings from just five major industrial categories (food, aluminum, cement, pulp and paper, and iron and steel). (16) The potential for cogeneration is indeed enormous. One estimate of the energy that could have been saved in 1975 is $14 \%$ of the national energy consumption, or 5.1 million barrels of oil daily. (3) The refuse produced within a city of average U.S. climate could supply enough heat to meet the full needs of about $7 \%$ of the city's population. (10) of course, these are theoretical potentials that could reach fruition only with the immediate widespread implementation of heat recovery and cogeneration plants in combination with aquifer thermal energy storage systems. And the most optimistic projection would not forecast that even a small fraction of these projects would be undertaken within the next decade, given institutional constraints and limited capital resources.

Over the long term, as society begins to appreciate the value of recovering waste energy, there will be increasing competition for it, and the potential energy supply available from the industrial sector for aquifer storage is likely to diminish. It is likely that in-house conservation measures will prove most cost-effective in many cases, and will absorb some of the presently wasted energy now available for ATES systems. A primary steel plant 
is a good example. The total waste energy from a single electric arc furnace could supply the annual space heating needs of 3,900 single family homes, given an efficient storage and distribution system. That same energy, combined with short-term thermal storage, could be recovered and used to generate electric power at the steel plant, reducing its electric demand by about $3 \mathrm{MW}_{\mathrm{e}} \cdot{ }^{\text {(17) }}$ other scenarios are also possible. The energy could be recovered and exported immediately to a customer capable of using a fluctuating energy source. Short-term storage could be employed to produce nonfluctuating energy for an external customer. And finally, alternative long-term storage modes could be employed. The selection of the end use for the waste energy will be very site-specific, dependent upon economics, energy availability, and a host of other factors. This trend toward utilizing internal waste heat should be more than compensated for, however, by the introduction of cogeneration into existing and newly constructed electrical power plants. 


\section{SYSTEMS ECONOMICS}

There are two general approaches to evaluating the economics of energy production systems. One is a cost evaluation in terms of dollars, typically employed by potential energy system developers as the major criterion in development decisions. The second is a cost evaluation in terms of energy consumed: a net energy analysis. The National Energy Act mandates this latter assessment as part of the federal evaluation process for new energy technologies. Both approaches are generally made on a life-cycle costing basis.

A net energy analysis is a determination of the net energy made available to society by an energy production system after the energy consumed or lost in the process has been accounted for. Advocates of this approach maintain that conventional economic evaluations of energy production processes fail to determine the true cost of production to society by failing to account for the economic subsidies provided to energy production processes. Generally the energy cost has two components: 1) the fuel consumed in the generation and delivery process and 2) the fuel consumed in the manufacture of the capital components of the production and delivery equipment.

A net energy analysis of an ATES system can be extremely favorable or very marginal, depending upon the approach taken. If one were to define input energy as primary fuel and electricity consumed, and did not include the energy stored (since it would have been wasted without aquifer thermal energy storage), then the net energy analysis would be highly favorable. If one were to include the stored energy as an input, then the net energy analysis would likely indicate a poor performance because of the heat lost to the aquifer during the storage cycle.

One analysis of alternative space heating modes indicates that coalfired district heating systems consume only 58\% as much primary energy as al1-electric systems and on 1 y $80 \%$ as much as gas/electric systems, with almost all of the life-cycle energy cost attributable to fuel consumption. If the hot water were to be provided by a waste heat/ATES system, a net energy analysis based on the primary fuels consumed is likely to show that 
the district heating system would consume only 5 to $10 \%$ as much energy as the competitive systems over system lifetime.

GENERAL COST CONSIDERATIONS

One key point needs to be made concerning the results of economic analysis for hot water delivery systems (including ATES). The cost of energy supplied is generally expressed in some common form, such as dollars per Btu $(\$ / B t u)$. That is, for any given time period, the cost of the energy supplied is equal to the total system cost (including all fixed and variable costs) divided by the number of Btu's supplied to the user. To put the energy cost of hot water-delivered heat on the same basis as heat delivered by other sources, the cost must be corrected for the efficiency of the user's space and water heaters. The denominator of the fraction must contain only the energy usefully consumed, not the energy lost to the chimney flue or cooling water stream. If one assumes a 70\% efficiency for the combustion of fossil fuels, then the cost of heat delivered must be 1.43 times the \$/Btu price paid for the fuel itself. Energy supplied by district heating systems and by electric resistance heating is essentially 100\% efficient, and no correction need be made.

Although no judgments of the economic feasibility of ATES systems can be made except on a case-by-case basis, there are several characteristics that will affect the economics of all ATES systems. One is that the energy delivered by a hot-water (or chilled-water) system is directly proportional to the change in temperature of that water at the point of end use. A district heating system that delivers water at $150^{\circ} \mathrm{C}$ and returns water at $70^{\circ} \mathrm{C}$ will be twice as cost-effective as the system that delivers water at $110^{\circ} \mathrm{C}$ and returns it at $70^{\circ} \mathrm{C}$ if all other parameters are the same between systems. This has a number of implications. Higher temperature systems have the potential to be more cost-effective than do lower temperature systems since the potential for temperature drop is greater. Furthermore, systems which circulate chilled water are at a decided disadvantage because maximum temperature change at the point of end use is probably limited to about $14^{\circ} \mathrm{C}\left(25^{\circ} \mathrm{F}\right)$. The 
minimum feasible delivery temperature for the water after cooling, storage, and delivery heat gains are accounted for is probably around $4^{\circ} \mathrm{C}\left(40^{\circ} \mathrm{F}\right)$; the maximum reject temperature for direct space cooling is about $18^{\circ} \mathrm{C}\left(65^{\circ} \mathrm{F}\right)$.

Perhaps the most pervasive characteristic of ATES systems is that they will be capital-intensive. Geothermal district heating system costs are typically about $60 \%$ fixed, ${ }^{(14)}$ and it is likely that ATES district heating systems costs will be similarly structured, although payment for waste heat or cogenerated hot water may constitute a significant variable cost in many cases. This characteristic has some major implications for the viability of potential ATES systems.

The first implication is that ATES systems will typically require large sums of capital during construction, especially if district heating is involved. In many cases these costs will lie beyond the capabilities of local municipalities and other potential operators, and some form of government support may be necessary.

A second implication is that the mode of financing can greatly affect the ultimate cost of delivered energy. Private companies generally have a high cost of capital compared to public agencies because their investors demand a high rate of return and the companies are subject to taxation. Municipalities are exempt from income and property taxes, and they can issue tax-exempt securities to raise capital, thereby securing a lower interest rate in the market. Some estimates put the cost of geothermal energy delivery $30 \%$ higher for private financing than for municipal financing, even when a $10 \%$ investment tax credit is allowed the private operation.

The third implication of the capital intensiveness of ATES installations is that the cost of energy delivered will probably increase at a lower rate than inflation, whereas competitive energy supply modes are likely to escalate at a rate greater than general inflation, as low-cost fuel supplies become scarcer. For ATES systems that employ a free energy source (such as solar energy or winter chill), the only price increases will be for pumping energy and for operations and maintenance. Waste heat and cogeneration energy prices are likely to escalate with time. 
Since the economics of potential ATES installations is so site-specific, one approach to an overall economic evaluation is to evaluate the technology's components (energy collection, storage, transmission, and end use) piece by piece. The economics of the latter two components is well documented, since these parallel existing district heating systems. The economics of the first two components is less well documented on a general basis, and probably more variable on a case-by-case basis.

ENERGY COLLECTION COSTS

The collection of energy for storage and subsequent delivery to users will generally incur a high fixed cost, with the extent of the variable cost dependent upon the type of energy source. Capture of waste energy may require installing expensive heat exchangers, redesigning certain portions of the plant, and working around ongoing plant operations during retrofitting. These costs may be partially or wholely offset for new installations, however, by reductions in the capital equipment needed to treat thermal pollution. The price of waste heat energy collected is likely to become significant in the future, especially as the competition for available forms of waste energy increases in intensity. The most attractive waste energy sources (in terms of temperatures and amounts of heat available) may eventually command rather high prices whereas the low-temperature forms may be available free, or for token prices. Thus the attractiveness of waste energy forms may tend to be equalized for ATES.

Implementing cogeneration as an energy source for ATES installations will require increased capital investment over electric-only generation plants. A relatively large investment cost may be expected for retrofit operations where considerable equipment may need to be replaced. In newly designed plants, however, the capital costs should be moderate since 1) a portion of the capital investment will be recovered from electricity revenues, and 2) the reductions in thermal pollution treatment equipment will be substantial. One design of a cogeneration plant rated at $600 \mathrm{MW}$ electric and $1200 \mathrm{MW}$ thermal indicates that heat and power can be generated at $30 \%$ lower cost than in conventional plants. Fuel consumption would be $20 \% 1$ ess and investment $\$ 208$ million less. 
Recovery of solar energy and winter chill will be almost free from a variable cost standpoint, but the capital costs may be high. Solar heat collection is expensive due to the diffuseness of insolation and the high cost of collectors. Technological improvements will probably be necessary to make the ATES storage of solar energy economically viable. The collection of chill may or may not be expensive, depending upon the climate and the requirements imposed by the aquifer. If the climate and aquifer allow spray pond chilling of the water, then costs will be minimal, reflecting only pumping and related activities. If, however, the climate and/or the aquifer indicate that simpler cooling modes are infeasible, more expensive heat exchangers or cooling towers will be required.

STORAGE-RELATED COSTS

The cost of ATES storage is primarily determined by the peak power characteristics of the system, rather than by total energy stored (as is typical of "container-limited" energy storage technologies). The reason is that most of the storage cost is attributable to the capital cost of the wells, and the number of wells is determined by peak input or output flow rates. Conversely, since aquifer utilization is essentially free (and limitless), capital cost is independent of the amount of energy supplied over a season.

Well costs are primarily determined by four parameters: well flow rates (which depend upon the aquifer flow characteristics), well-drilling costs, well life, and aquifer depth. Operating expenses such as maintenance and pumping energy will be small with respect to capital cost unless shallow, inexpensive wells are utilized. Another continuing cost, well-redrilling, could prove substantial if well life is unusualiy short.

A major storage-related cost is the cost of energy not recovered from the aquifer. While this is not an actual cash flow, its implications for the cost of delivered energy are considerable. If the aquifer is $70 \%$ efficient, then all energy collection and storage fixed costs and many of the variable costs must be amortized over 70 units of energy sold, rather than over a possible 100 units of energy sold. This storage loss can be expected to decrease over time since aquifer efficiency should improve (although at a decreasing rate) over the life of the project. 


\section{FLUID TRANSMISSION COSTS}

Costs for delivery of the thermal energy to the user are related primarily to the distance between the user and the withdrawal wells. Piping costs are a function of peak demand, size of the heat demand, and other site-dependent factors, including the terrain, cost of the right-of-way, and whether pipe burial is required. Peak demand is an important characteristic because the peak flow rate determines the pipe size. A system that can maintain a steady energy delivery rate will fare better economically than one characterized by severe changes in flow rates since pipe costs will be minimized on a per Btu-delivered basis. Pipeline costs (including all capital equipment and installation costs) tend to increase linearly with the radius of the pipe, whereas capacity increases with the square of the radius. A large demand can be served more economically than a smaller market since significant economies of scale are captured with large pipes.

END USE-RELATED COSTS

The end-use-related costs can be a major portion of total costs for district heating systems if one includes the in-city distribution network. For a process heating system, however, they may constitute only an insignificant fraction of the costs, especially if hot water is already used as the heating medium.

For district heating there are numerous important cost factors, including climate, community characteristics, and construction conditions. The climate affects district heating costs in two ways. The minimum exterior temperature establishes the peak load requirements and, hence, the pipe sizes in the distribution network. The number of heating degree days establishes the annual energy usage and, therefore, the energy base over which the total costs must be amortized. The total population influences district heating costs through capture of economies of scale. Population density is a very important factor. Increasing population density reduces cost by reducing the average length of pipe run between users.

The costs of pipeline construction are highly dependent upon the terrain and the degree of urbanization, with probably a factor of ten difference in 
Recovery of solar energy and winter chill will be almost free from a variable cost standpoint, but the capital costs may be high. Solar heat collection is expensive due to the diffuseness of insolation and the high cost of collectors. Technological improvements will probably be necessary to make the ATES storage of solar energy economically viable. The collection of chill may or may not be expensive, depending upon the climate and the requirements imposed by the aquifer. If the climate and aquifer allow spray pond chilling of the water, then costs will be minimal, reflecting only pumping and related activities. If, however, the climate and/or the aquifer indicate that simpler cooling modes are infeasible, more expensive heat exchangers or cooling towers will be required.

STORAGE-RELATED COSTS

The cost of ATES storage is primarily determined by the peak power characteristics of the system, rather than by total energy stored (as is typical of "container-limited" energy storage technologies). The reason is that most of the storage cost is attributable to the capital cost of the wells, and the number of wells is determined by peak input or output flow rates. Conversely, since aquifer utilization is essentially free (and limitless), capital cost is independent of the amount of energy supplied over a season.

Well costs are primarily determined by four parameters: well flow rates (which depend upon the aquifer flow characteristics), well-drilling costs, well life, and aquifer depth. Operating expenses such as maintenance and pumping energy will be small with respect to capital cost unless shallow, inexpensive wells are utilized. Another continuing cost, well-redrilling, could prove substantial if well life is unusually short.

A major storage-related cost is the cost of energy not recovered from the aquifer. While this is not an actual cash flow, its implications for the cost of delivered energy are considerable. If the aquifer is $70 \%$ efficient, then all energy collection and storage fixed costs and many of the variable costs must be amortized over 70 units of energy sold, rather than over a possible 100 units of energy sold. This storage loss can be expected to decrease over time since aquifer efficiency should improve (although at a decreasing rate) over the life of the project. 


\section{FLUID TRANSMISSION COSTS}

Costs for delivery of the thermal energy to the user are related primarily to the distance between the user and the withdrawal wells. Piping costs are a function of peak demand, size of the heat demand, and other site-dependent factors, including the terrain, cost of the right-of-way, and whether pipe burial is required. Peak demand is an important characteristic because the peak flow rate determines the pipe size. A system that can maintain a steady energy delivery rate will fare better economically than one characterized by severe changes in flow rates since pipe costs will be minimized on a per Btu-delivered basis. Pipeline costs (including all capital equipment and installation costs) tend to increase linearly with the radius of the pipe, whereas capacity increases with the square of the radius. A large demand can be served more economically than a smaller market since significant economies of scale are captured with large pipes.

END USE-RELATED COSTS

The end-use-related costs can be a major portion of total costs for district heating systems if one includes the in-city distribution network. For a process heating system, however, they may constitute only an insignificant fraction of the costs, especially if hot water is already used as the heating medium.

For district heating there are numerous important cost factors, including climate, community characteristics, and construction conditions. The climate affects district heating costs in two ways. The minimum exterior temperature establishes the peak load requirements and, hence, the pipe sizes in the distribution network. The number of heating degree days establishes the annual energy usage and, therefore, the energy base over which the total costs must be amortized. The total population influences district heating costs through capture of economies of scale. Population density is a very important factor. Increasing population density reduces cost by reducing the average length of pipe run between users.

The costs of pipeline construction are highly dependent upon the terrain and the degree of urbanization, with probably a factor of ten difference in 
costs between the most difficult and least difficult construction conditions. Cost estimates for retrofitting of buildings for hot water heating are highly variable. One cost estimate is $\$ 500 /$ residence (for forced air systems), and $\$ 2000 /$ residence (for electric resistance heating). gives $\$ 3120$ and $\$ 4960$, respectively (1985 dollars).

Another estimate

The transmission and distribution costs, and even some of the we11related storage costs, can be reduced by designing the system capacity to meet less than peak demand in district heating applications. In this way the load factor can be increased, with a resultant cost savings for the energy delivered. Individual boilers within the distribution system could raise the water temperature sufficiently to enable in-house heating equipment to meet peak heat demands.

\section{EXAMPLES OF ATES COST EFFECTIVENESS}

At least two site-specific ATES applications have been evaluated on a detailed basis: a cooling system for the John F. Kennedy Airport in New York, (21) and a cogeneration-district heating system for MinneapolisSt. Paul. (2)

The cooling system for JFK Airport was found to be economically infeasible. Energy consumption would have been reduced, but savings would have been insufficient to recover the capital investment over the life of the project. Undoubtedly part of the cost ineffectiveness can be attributed to the minimum energy content of the chilled water. Most of the difficulty appears to be site-specific, however. Installation of the proposed system would have involved the erection of large cooling towers, the construction of pipelines over marshland, and extensive tunneling under the runways of an operating airport. In addition, New York City is probably the most expensive labor market in the contiguous United States. The authors of the study are careful to note that their results cannot be interpreted as a condemnation of the district cooling concept.

The cogeneration-district heating study for the Twin Cities concluded that the potential benefits of incorporating aquifer thermal energy storage were substantial. Several possible scenarios were evaluated. The best case 
resulted in a net annual energy savings of $36.9 \times 10^{12}$ Btu (about $32 \%$ of the total energy required without ATES) even when a $25 \%$ heat loss was assumed during storage. This translates into an annual fuel cost savings of $\$ 31$ million. The break-even capital cost for ATES development was found to be $\$ 76 / \mathrm{kW}$ thermal after a life-cycle costing analysis. This is far above the estimated ATES development cost of $\$ 23$ to $\$ 50 / \mathrm{kW}$ thermal. Numerous other benefits would be realized, including:

- saving the cost of installing boilers

- avoiding problems of siting boilers at each transmission node

- avoiding air pollution problems of dispersed boilers

- replacing oil burned in boilers with coal burned at central plants

- operation of cogeneration equipment at higher capacity factor

- substitution of backpressure turbines instead of extraction turbines, thus increasing the efficiency of cogeneration

- reducing the amount of cogeneration capacity required

- reducing the size, cost, and heat losses of transmission pipelines. 


\section{THE POTENTIAL MARKET}

The potential market for thermal energy withdrawn from ATES systems is quite extensive, limited only by the economics of application. The market falls naturally into three segments: space heating and cooling, industrial process heat, and agriculture (including aquaculture). Total national energy consumption in 1977 was 75.8 quads. Space heating and cooling of residential and commercial sectors (which includes hot water heating for sanitary purposes) totaled 19 quads or $25.0 \%$ of total consumption. Process steam and direct heat in the industrial sector totaled 15.4 quads or $20.3 \%$ of the total. (23) Agriculture consumed about 2\% (1.5 quads), chiefly in the form of liquefied natural gas (LPG) for the drying of grain, crop curing, and space heating.

The three market segments exhibit other differentiating characteristics besides application. First, the temperature regimes of thermal energy employed are different: Agricultural uses are suited to extremely low grade heat, on the order of $40^{\circ} \mathrm{C}\left(100^{\circ} \mathrm{F}\right)$. Residential space heating uses water from $50-100^{\circ} \mathrm{C}\left(120-212^{\circ} \mathrm{F}\right)$, and most process heat requirements are for temperatures above $100^{\circ} \mathrm{C}\left(212^{\circ} \mathrm{F}\right)$. Second, the major users within each of the segments will probably be separated geographically from major users in the other segments. That is to say, factories will generally not be found surrounded by farmlands, which in turn will not likely be next to densely populated residential developments. And third, the time horizon for application of ATES technology is likely to differ between segments. Single-owner developments may be the first to be implemented, since they involve a minimum of institutional, financial, and construction-related problems. These will most likely be for supply of process heat, or for the supply of space heating to single, large commercial/residential complexes. District heating of the residential sector, with all the attendent institutional problems and the 5 to 10-year construction time, will probably follow later. The timing of ATES application to agricultural use is not so easily predicted, as commercialization depends less upon technical or institutional factors than upon the economic feasibility of the particular circumstances at hand. 
These major differences seem to indicate that, at least in the short term, ATES developments will be designed for single-purpose use only, with only incidental applications in the other sectors. Later, after experience is gained with the technology, larger multi-purpose systems may come into being. This line of reasoning does not imply that such dual-purpose systems are impossible; neighboring users from two or three different segments might find themselves ready for ATES development simultaneously. In such a situation the same ATES development could be applied to each, with either the fluid diluted with cold water to meet the needs of the low-grade heat user, or the fluid temperature augmented by heat pumps or boilers to meet the needs of the high-grade heat consumer. Flexibility is a major attraction of the technology.

THE POTENTIAL FOR DISTRICT HEATING

District heating systems have not been realized to any significant degree in the United States. To some extent this has resulted from custom and institutional barriers, but for the most part it reflects the condition that consumers could generally meet their space heating and hot water needs more cheaply with individual heating systems than with district heating systems. Furthermore, most early United States district heating systems employed steam as the medium for energy delivery, a mode not conducive to largescale systems because of technical limitations. The recent large increases in the cost of fossil fuels have made district heating systems more attractive, however, and the relative attractiveness should continue to increase as fossil fuels and electricity grow even costlier. The continued national trend to urbanization and multi-family housing units should further serve to encourage implementation of district heating systems.

Perhaps the best indicator of potential implementation of district heating in the United States is the European experience. These nations, without the system of petroleum price controls that is only now ending in the United States, have been faced with expensive fuels for many years. Denmark is a prime example of a country which has espoused district heating as a solution to its energy cost and availability problems. (Ninety-six percent of its fuel has had to be imported.) About $35 \%$ of its houses participate in one of 
the more than 450 different district heating systems in this country with only half of the land area of the state of Maine. (24) Sweden, Germany, and other northern European countries with winter climates commensurate with that of the mid and northern United States also are relying ever more heavily upon district heating. The Soviet Union is the world leader, with fully $54 \%$ of its entire population and $70 \%$ of its urban population heated by district heating. (10) These figures, of course, reflect a planned economy and the dearth of single-family housing.

Several studies have been made of the potential market for district heating in the United States. Estimates from these indicate that the costs of district heating would be competitive for $20 \%$ to $50 \%$ of the total population. One of these investigations resulted in the following conclusions:

In summary we find that between 50 and 55 percent of the United States population could be served by district heating at current economic levels (1977) dictated by foreign oil prices. Total investment in district heating systems is estimated at $\$ 180$ billion: the resultant oil conservation of $1.1 \times 10^{9}$ barrels per year. . would translate into a reduction in foreign payments of $\$ 13$ billion per year. In terms of national benefit, the district heating scheme would pay for itself after 14 full years of operation at maximum implementation, or sooner if imported crude oil were to increase in price. (10)

These estimates are each several years old and use pre-1980 fuel prices. It is likely that the estimates of market penetration potential would be increased at today's fuel prices.

THE POTENTIAL FOR INDUSTRIAL PROCESS HEAT

Considerable information has been generated by solar and geothermal research groups on the demand for industrial process heat in various temperature ranges. This information indicates that there is a vast range of potential applications for hot water energy supply, ranging from washing and cooking to more esoteric uses such as protein development and gasohol production. The potential scale of such applications is also enormous. Approximately $7 \%$ of total process heat is used below $100^{\circ} \mathrm{C}\left(212^{\circ} \mathrm{F}\right)$, and about $28 \%$ is used below $288^{\circ} \mathrm{C}\left(550^{\circ} \mathrm{F}\right)$. If the assumption is made that hot water could be used to preheat those elements involved in higher tempera- 
ture processes, then $27 \%$ of process heat could be supplied by water at $100^{\circ} \mathrm{C}\left(212^{\circ} \mathrm{F}\right)$ and $52 \%$ by water at $288^{\circ} \mathrm{C}\left(550^{\circ} \mathrm{F}\right)$ or below. These correspond roughly to 5 and $10 \%$ of total national fuel consumption, respectively. (25) These moderate temperature needs are difficult to meet efficiently with either electricity or fossil fuels, as is indicated by the poor thermodynamic performance of most of the present systems supplying such needs and the resultant thermal pollution problems. Using cogenerated hot water to supply the heat for these industrial processes would greatly improve thermodynamic performance and reduce energy costs.

Most of this process heat utilization is not seasonal, however, and the need for storage systems to supply energy is questionable since the processes could probably be linked directly to hot water cogeneration units or waste heat units. The most likely user of ATES-generated energy is a seasonal user of process heat, such as is typical in the food preparation industry. There are situations, however, where ATES systems can be foreseen for continuous users. For example, it might be advantageous for a user to install his own aquifer storage system to ensure a continuous supply of energy when he has access to a low-cost, but intermittent, energy supply. A second likely continuous energy user is a solar energy supply system that employs seasonal storage to levelize annual input into the system so as to minimize collector area and eliminate backup systems.

Six of the 22 major industrial groups account for $80 \%$ of all purchased energy used in manufacturing, and so a brief investigation of these presents a good overview of the potential for ATES-supplied energy. (26) They are:

- Primary Metals: Characterized by high-grade energy use for heating to very high temperatures, and electricity for drives and electrolysis. Some steam is generated, but it is chiefly for mechanical drives and electricity generation. The potential for direct use is quite small.

- Chemical and Allied Products:

This sector contains myriad potential applications, with the major users being production of chlorinecaustic soda, ash, alumina, and sulfur by the Frasch method. 
- Petroleum/Coal: Eighty to ninety precent of the process steam requirements could be met by hot water at or below $250^{\circ} \mathrm{C}$ $\left(480^{\circ} \mathrm{F}\right)$.

- Paper and Allied Products:

All of the need for steam, which is quite large, can be met by low-temperature water. The industry does have the potential to use great quantities of self-generated fuels, however, which might limit the potential market.

- Stone, Glass, CTay, and Concrete:

- Food and Kindred Products:

Requirements are characterized by very high temperatures. The potential for direct use is quite small.

Considerable energy demand for process steam and refrigeration (usually supplied by hot water absorption chillers), and for cooking, cleaning, and sanitizing. Much of this demand is seasonal, making ATES-generated energy highly suitable.

One process use of hot water that currently has only minimal scale, but has the potential to utilize vast quantities of waste heat, is the production of alcohol for use in gasohol. Fuel-grade alcohol can be made from essentially any organic material (including forest and farm wastes and sewage sludge). The problem with its manufacture, however, is that the process is highly energy-intensive, requiring from 40,000 to $70,000 \mathrm{Btu}$ 's per galion produced, or about one-half of the net energy available from the finished product. Waste heat could be used to: 1) heat the water for the fermentation process, 2) supply energy for the distillation step, and 3) dry the byproduct solids. (27) Trial plants using hot water from geothermal wells are now in the planning and construction stages.

Other potential uses for hot water-supplied process heat include:

- sludge drying for fuel and fertilizer production

- distillation of water

- kiln drying of lumber

- aggregate drying

- conversion of cellulosic wastes to protein through use of thermophyllic bacteria 
- methanol production from coal

- alfalfa and tobacco drying

- salt production by evaporation

- single-cell protein production

- hydrogen production from thermophyllic bacteria

- leaching uranium from shale

- chemical cleaning of coal

- ice melting on bridges and at airports.

POTENTIAL FOR AGRICULTURAL USE

Agriculture and the related field of aquaculture appear to hold unlimited potential for the utilization of waste heat from ATES systems, at least from a technical viewpoint. Numerous pilot operations and in-the-field tests have demonstrated the ability of properly applied waste heat to increase the yield of existing crops and to enable cultivation of crops in areas previously too cold for those particular crops. Usage is generally seasonal, and the waste heat used is generally in the low-temperature range, where there is little competition for waste heat.

The major constraint on widespread use of ATES-supplied energy for agriculture and aquaculture is the lack of demonstrated economic feasibility. Augmented agriculture production has yet to demonstrate widespread cost effectiveness, even when the heat is used directly. Whether cost effectiveness can be demonstrated for agriculture using seasonally-stored energy remains to be seen. Some major potential uses under investigation include:

- Heating and cooling of greenhouses. This area shows the best chance of economic feasibility, especially for cultivating high-value, low-space produce such as tomatoes, and for flower-growing.

- Environmental control for livestock housing.

- Soil warming through the circulation of warm water in pipes. This is primarily a technique for extending the length of the growing season, 
thereby allowing multiple crops during the same year, or for cultivating a crop normally grown only in a longer growing season.

- Direct soil warming through irrigation with warm water.

- Warming of bays or artificial ponds for the development of algae, shrimp, salmon, and other marine or fresh-water foodstuffs for man or animals. This application appears to be economical in some circumstances if the technical difficulties can be worked out. There are problems with disease, with pollution, and with control and reliability of temperatures.

- Recovery of nutrients from livestock wastes.

- Grain drying.

One agricultural use of fossil fuels that has emerged in the past decade is for drying grains, particularly corn. The 1972 demand for corn drying energy was $56 \times 10^{12} \mathrm{Btu}$, with almost all demand occurring in a 3-month period after early October. (28) The corn is generally dried in continuous flow units at temperatures between 130 and $170^{\circ} \mathrm{C}\left(260-340^{\circ} \mathrm{F}\right)$. The seasonal demand and moderate temperature requirements make grain drying an ideal use for ATES.

\section{MARKET PENETRATION RATES}

It is difficult to estimate the market penetration rate for district heating because its implementation in this country will be chiefly a function of a number of institutional factors. We can, however, estimate the time required for implementation of a single system after the decision to proceed is made, again by looking at the European experience. In Sweden, 300 to 400 MW systems have been constructed and put into full service within 5 to 10 years, with some service being made available almost immediately. (29) This is done through a three-step program: 1) Mobile hot water boilers are installed in some especially suitable areas with high load densities. The largest heat consumers are the first to be connected. These "district heating islands" are all built with the same design temperatures and pressures to facilitate later system connection. 2) Several of the district heating is- 
lands are interconnected, and a permanent central boiler plant is built to cover the needs of the interconnected area. Some of the smaller boiler plants may be retained for peaking purposes; most are moved to new heating islands. 3) A cogeneration plant is built to cover the baseload requirements of the system, leaving the cheaper hot-water boilers to cover the peaks and to act as a reserve to the main baseload unit. This approach has proved especially efficient in the widespread development of district heating; much of this efficiency can be attributed to the national plan for conversion to district heating, whereby interim equipment is continually recycled for the early stages of new developments.

The penetration rates for industrial process heat and agricultural uses of ATES-generated energy are also difficult to assess. Several case history studies, however, have been performed that look at the market penetration of a successful technology. One particularly relevant study examined 12 highly capital-intensive innovations in four heavy industries (coal mining, iron and steel, railroads, and brewing). ${ }^{(30)}$ It found that the adoption rate of a new technology that had already proven itself cost-effective followed an S-shaped curve. The adoption rate was strongly dependent upon rate of profitability, while investment size had a weak negative effect. There was little correlation of adoption rate with industry growth, national business conditions, time since first adoption, or remaining service life of the equipment replaced. The investigation did find a significant difference between industries, however. It is unclear whether such findings can be assumed for the ATES technology since applicablity depends on the existence of suitable energy sources, aquifers, and users within a short distance of one another. 


\section{LEGAL AND INSTITUTIONAL ISSUES}

The legal and institutional issues associated with implementation of the ATES concept can be conveniently divided into two categories. The first includes storage-related issues; the second includes issues associated with end use of the stored thermal energy. The latter category is likely to contain the more serious constraints to ATES development, most of them institutional in nature. None of them, however, appear insurmountable.

\section{REGULATORY REQUIREMENTS ASSOCIATED WITH ENVIRONMENTAL PROTECTION DURING STORAGE}

The major Federal environmental statute that will affect the storage function of ATES systems is the Safe Drinking Water Act of 1974. The Clean Water Act has some existing impact that will diminish as the Safe Drinking Water Act is phased in. The two statutes operate similarly. Under each, the Environmental Protection Agency (EPA) sets minimum standards for certain discharge practices and provides an overseeing function to ensure compliance. Those states which design Federally acceptable permit, monitoring, and enforcement programs and agree to enforce the EPA standards are subsequently delegated authority to operate their own programs, removing the EPA from the direct monitoring role in those states.

The Clean Water Act requires that before pollutants can be discharged into the waters of the United States, a permit must be obtained under the National Pollution Discharge Elimination System (NPDES). Heat is included within the definition of pollutants. The principal intent of the Act seems to have been protection of surface waters; however, control of underground discharges is provided for. States are required to control the disposal of pollutants into wells as a precondition to EPA approval of their NPDES Program. EPA underground injection requirements under the Clean water Act in states that do not administer their own NPDES Program are relatively weak and ordinarily would not apply to an ATES operation. The regulation simply requires that if an applicant for an NPDES permit proposes to discharge to wells as part of his program, EPA can specify additional terms and conditions in the permit. 
The Clean Water Act will become less important in the future as the Underground Injection Control (UIC) Program under the Safe Drinking Water Act of 1974 comes into effect. This program directs the EPA to:

- publish minimum national requirements for effective state UIC programs

- make grants to states for development and implementation of those programs

- review state programs and approve/disapprove them

- implement federally controlled programs for those states choosing not to participate in the program.

Final regulations under the Act are expected to be published in June, 1980 in the Federal Register.

EPA has divided injection wells into five categories under the UIC program. Examination of the classifications and preliminary discussion with the EPA Region 10 Office suggest that an ATES we 11 will probably fall into Class $V$, the general classification for wells not defined in the first four categories. Examples of Class $V$ wells include those for water table recharge, cooling water return, air conditioning return, and subsidence control. Class $V$ wells will be the last to be regulated, in part because little is known about potential health risks and environmental implications of this class of wells. EPA has proposed that owners/operators of these wells be required to submit a description of the well to the state within 6 months of the effective date of the UIC program. Within 2 years of that date, the state must submit to EPA an assessment of the contamination potential of Class $V$ wells, available corrective actions and their economic and environmental consequences, and recommendations for regulatory action. Final regulations for Class $V$ wells will probably not be published for 3-4 years. Class $V$ wells may be ordered to take corrective actions or even be ordered to close under the proposed regulations, if they are found to present a significant health risk.

It is likely that the final regulations applicable to Class $V$ wells will not present a serious obstacle to ATES. Rather, they are likely to require an injection permit and careful controls on aquifer selection (including aquifer depth and boundary materials), well-construction techniques and materials so 
as to insure mechanical integrity, proper injection, plugging and well-abandonment practices, and perhaps fiscal responsibility. As the title of the Act suggests, the main objective will be to protect ground water currently being used or potentially of use as drinking water.

If ATES wells are construed by EPA to come under Class I (industrial waste injection), which is highly unlikely, regulation will be more intense and will occur sooner. Use of an aquifer that is a source of drinking water will probably not be possible in this case.

EPA has proposed a consolidation of UIC and NPDES permit requirements. The proposed regulations encourage, but do not mandate, that states with permit-issuing authority adopt consolidation procedures. Under the consolidated regulations, UIC and NPDES requirements would be satisfied by a single permit under the state UIC program, except in the unusual case where EPA controls one program and the state the other.

Until the state UIC programs become effective, a state permit for underground injection, or an EPA permit in cases where the state does not have authority to operate the NPDES system, will be required. None of the permit requirements is expected to be a serious obstacle to ATES development.

There is a third environmental statute that might come into play if the federal government becomes involved in the financing, operating, permitissuing, or other aspects of heat storage wells. The National Environmental Policy Act (NEPA) requires federal agencies to prepare a detailed environmental impact statement (EIS) for each major federal action significantly affecting the quality of the human environment. The determination of which actions are major and which actions significantly affect the human environment is not always clear. Decisions on which ATES installations require EIS preparation will be made on a case-by-case basis. A state EIS for certain demonstration or commercial projects may be required if no NEPA EIS is required. EIS preparation may also be required for major end-use developments, such as construction and operation of a district heating system. 
A second set of storage-related issues concerns protection of the energy resource once it is stored underground. Like the preceding regulatory issues, protection issues are reasonably important but seem to pose no serious obstacles to ATES development.

The major concern is whether the injected hot water can be protected from withdrawal by outsiders. Investigation of this issue requires consideration of the ownership of subterranean space. Historically, the land owner has had the sole right to occupy the total vertical space above and below his land, although separation and transfer of mineral rights and air rights has been permitted. In modern times the courts have ruled that air space rights extend only to a reasonable distance above the ground, and that normal air traffic does not involve in a taking of property. The law of subsurface space also seems to be moving in this direction.

As long as the stored energy resource underlies the surface land owned by the injection entity, there is no question of ownership. Often this will be the case. (One investigator, for example, estimates that injection of one million gallons per day into a $100 \mathrm{ft}$ thick aquifer would result in a heat pocket with only a 240-ft radius after 90 days.) (3) If, however, the water does extend beyond the owned surface land, a central question is whether the adjoining land owner could withdraw the water without paying damages. The question of unauthorized withdrawal is apparently unsettled. The adjoining land owner could intentionally or unintentionally cause the hot water to migrate to his land by pumping his well and creating a pressure gradient towards his well. If the ground-water user pumps the energy resource in the normal course of exercising a ground-water right, recovery of damages by the ATES operator seems unlikely. If the user deliberately pumps the stored energy, recovery may depend upon proof of the intent of the user and whether his well depth is reasonable. In California, recent case law has recognized the right to store water in empty aquifer space without paying overlying owners and the right to protect the water from expropriation. The law in other states is unclear, although California courts have an impressive record 
of setting precedent in issues of this type. Case law is mixed on whether natural gas can be stored under non-owned land without loss of ownership. POTENTIAL LIABILITY ASSOCIATED WITH ATES

The third storage-related issue is the possibility of liability associated with ATES. The most likely source of liability is thermal pollution of water withdrawn from a well on adjacent or nearby land. Less likely sources are chemical contamination of the well water and interference with other underground property rights such as mineral rights or consumptive uses of ground water. Migration of hot water in the aquifer to areas where the storing entity does not have surface ownership may technically be a trespass. Damages would likely be nominal, however, unless a specific harm or loss could be shown. If the injured party can show harm or loss from contamination, it would be possible for him to pursue a private civil remedy. Most likely he would pursue a tort action and contend that the ATES entity either was negligent or had committed a private nuisance. The theory of trespass is also a possibility. The injured party must show that the ATES entity was unreasonably polluting the ground water. The pollutant could be heat, chemical contamination, or both. The plaintiff could ask for damages and perhaps even an injunction against the activity. An injunction seems unlikely if the storing entity had obtained a permit for the activity, but monetary damages, if shown, are not out of the question. Any plaintiff would have to show that his harm or loss was caused by the ATES activity to recover.

The ATES concept does not involve a consumptive use of water. Nevertheless, it is conceivable that an ATES project could temporarily affect, or be accused of affecting, the quantity of ground water available to other users. The common law bases for liability have been incorporated into the Restatement (Second) of Torts (Section 858 [1977]). The Restatement formulation provides that a withdrawer of water for a beneficial purpose is not subject to liability for interference with the use of water by another unless:

a. the withdrawal of water unreasonably causes harm to a proprietor of neighboring land by lowering the water table or reducing artesian pressure, or 
b. the quantity of water withdrawn is unreasonable, or

c. the withdrawal directly affects the quantity of water in a watercourse or lake and unreasonably harms a person entitled to the use of its water.

The questions of trespass, loss of ownership, and even injection and extraction of water will be significantly complicated if the aquifer crosses state lines. Not only will different permitting agencies become involved, but the applicable law on these questions may be different.

A final storage-related concern is the possibility of underground use conflicts. Such a conflict might occur when the energy stored within the aquifer overlaps with other underground uses such as mineral extraction, underground waste disposal, or location of pipes or cables. With adequate planning, these use conflicts can probably be minimized. It may be desirable for the ATES entity to purchase the mineral rights along with surface rights to minimize any chance of conflict.

In summary, the legal/institutional storage-related issues need to be considered prior to ATES development, but they are unlikely to significantly restrain establishment of ATES systems.

END USE ISSUES

The institutional issues associated with commercial use of the stored energy may pose more serious constraints to ATES use and development than the storage-related issues. However, none of the constraints should prohibit development, and they can almost certainly be overcome if the economic and conservation incentives for development are sufficiently attractive.

The institutional issues are simplest when the end user is a single industrial consumer or a limited number of cooperative commercial users (such as a shopping center). In cases of this type, the companies themselves may finance the construction of a distribution system; moreover, it may be possible to set the terms of energy delivery by negotiation rather than through a regulatory body. 
When the end use of energy is for district heating of private residences, the regulatory and institutional issues will quickly become more numerous and complex. There are at least four main institutional issues:

- What entity will take the initiative to arrange for energy storage and distribution?

- How will transmission and distribution lines and space heating retrofit equipment be financed?

- What should the service area be, and should hook-up be mandatory?

- What price should be charged for the delivered energy?

The first issue is a key one for development of a district heating system. Unless one entity takes the initiative to enlist individuals, businesses and governmental organizations, commercial development of the concept may never be realized. Finding the organization with sufficient interest to "push" the concept may not be easy. A user might accept hot water service in lieu of natural gas or electricity if the substitute were of equal or better quality, and the costs were not greater, but it is doubtful that individual home owners would ever push for such a system.

Similarly, there is no reason to expect a push for district heating from the supply side. A utility embarking on such an innovative development cannot predict how long regulatory approval will take. Nor can it predict how the benefits that accrue to the new technology will be allocated between the customers and the utility. Operation of a district heating system may provide less rate base and consequently less profit than a steam electric power plant. Furthermore, many utilities also market natural gas, and there would be little incentive to implement a district heating system if existing customers are displaced. There are at least 44 entities that market district heating steam in the United States, ${ }^{(31)}$ but these are predominantly small sideline operations of major electricity producers. The overall market has been stagnant for decades; although small campus-type heating systems have been on the increase, there appear to be no enormous incentives in the private sector for the implementation of district heating. Water-delivery utilities, due to their expertise and the possession of distribution easements, are the likely 
operators of the ATES district heating systems. But many of them are too small to undertake such capital-intensive projects, and they may hesitate to enter a new field of endeavor such as energy supply.

The issue of financing also is important if residential space heating is to be one of the end uses of the stored energy. Since district heating systems are so capital-intensive, the methods of financing can vary the cost of delivered heat by up to $30 \%$. Financing will be needed for main transmission lines, for distribution networks, and, in many cases, for retrofit of heating systems in existing houses. Costs will easily run to tens of millions of dollars for even a small to medium size city. Revenue bonds are perhaps the most likely funding source for the transmission and distribution system. Retrofit conversions can be financed in various ways, with financing provided by the marketing utility the most likely. HUD funds or FHA-insured loans are also potential financing sources. The availability of private financing will depend upon investor confidence in the commercial feasibility of the district heating system, and the potential for economic return. With the escalating price of alternative fuels, the economic attractiveness of district heating should quickly improve.

Both of the aforementioned issues--the probable lack of institutional push for district heating systems and the capital intensity of these systems--indicate that district heating may never come into widespread realization in the United States without major impetus from government. The primary benefits of district heating, conservation of scarce energy resources, reduction of pollution, and improvement in the balance of payments deficit, are more readily perceived at the national or state level than at the local implementation level. Hence it is government that may need to provide incentives to possible ATES/district heating operators. This type of governmental involvement has typified the district heating experience in most of the European countries that make extensive use of district heating.

The question of mandatory hook-up to a district heating system is also a significant issue. The economics of district heating are strongly dependent upon the density of users, and it may be that virtually $100 \%$ participation is 
necessary for cost-effective service in many situations. To effect such participation, either the price of energy must be significantly less than the price of competing energy sources, or else participation must be made mandatory. While a mandatory hook-up policy may seem foreign to the American way of life, there are precedents. California and some local governments have begun to explore proposed regulations, ordinances and standards concerning the energy source, and the type and size of heating equiment. The San Diego County Board of Supervisors has passed an ordinance prohibiting issuance of building permits for new residential buildings that do not use solar energy systems as the primary means of heating water.

Pricing of the energy delivered by a district heating system is a related institutional issue. A principal distinction of district heating systems is that much of the energy cost is for retirement of fixed capital costs and that variable costs are minimal. Consequently, heat delivery costs will almost certainly rise much more slowly than the costs of alternative space heating options. An important question, then, is whether initial prices should be set artificially low with planned future price increases to recover early losses or whether initial prices should be set so as to provide an economic return to the investors from the outset. The former strategy might encourage virtually full participation without mandatory hook-up, but it would involve additional financing problems or government subsidy. The latter strategy would unfairly burden the original participants, who would have to carry the load until it was advantageous for others to participate.

The question of how the district heating entity will be regulated will depend in part on whether it is publicly or privately owned. Regulation, at least at the state level, will likely be much more intense for an investor owned district heating company. A municipal utility is likely to have more latitude, subject to approval by local governing authorities.

Various other issues are also important to the development of a heat storage and delivery system. These include taxation and possible tax incentives at the Federal, state, and local levels; construction-related impacts; and the institutional mechanisms that can encourage the conversion of elec- 
trical plants to cogeneration plants. Background work has been done on all these issues plus those previously discussed. The evidence suggests that with sufficient economic incentives, none represent an insurmountable obstacle to development of ATES and heat delivery systems. 


\section{REFERENCES}

1. U.S. Department of Energy, Multi-Year Plan for Thermal and Mechanical Energy Storage Program, DOETET-0T09 (Draft), June 1979.

2. Meyer, C.F., Potential Benefits of Thermal Energy Storage in the Proposed Twin Cities District Heating-Cogeneration System, General Electric Company-TEMPO, Santa Barbara, CA, June 1979.

3. Meyer, C.F., Hausz, W., et al., Role of the Heat Storage Well in Future U.S. Energy Systems, General Electric Company-TEMP0, Santa Barbara, CA, T976.

4. Meyer, C.F., "Heat Storage Wells: Key to Large-Scale Cogeneration?" Public Power, July-August 1977.

5. Implementing Agreement for a Programme of Research and Development on Energy Conservation Through Energy Storage, International Energy Agency, September 1979.

6. Hooper and Angus Associates, Ltd., Study to Examine the Technical and Economic Feasibility of Using Aquifers as a Chilled Water Source or Storage Medium for Building Air Conditioning Systems, Volume I, Toronto, Canada, Aprit 1979.

7. Tsang, Chin Fu, "A Review of Current Aquifer Thermal Energy Storage Projects," International Assembly on Energy Storage, Dubrovnik, Yugoslavia, May 27-June 1, 1979.

8. Meyer, C.F., "Large-Scale Thermal Energy Storage for Cogeneration and Solar Systems," 5th Energy Technology Conference and Exposition, Washington, D.C., 27 February-1 March 1978.

9. Allen, R.D., Thermal Energy Storage in Aquifers - Preliminary Information, Pacific Northwest Laboratory, December 1979 (PNL-3062).

10. Karkheck, J., Powel1, E., and Beardsworth, E., "Prospects for District Heating in the United States," Science, vol. 195, March 1977.

11. Kazmann, P.E., "Underground Hot Water Storage Could Cut National Fuel Needs 10\%," Civil Engineering-ASCE, May 1978.

12. Ground Water and Wells, A Reference Book for the Water-Well Industry, Johnson Division, UOP Inc., Saint PauT, MN, 1975.

13. National Water Commission, Water Policies for the Future, 230 (1973).

14. Bloomster, C.H., Fassbender, L.L., and McDonald, C.L., Geothermal Energy Potential for District and Process Heating Applications in the U.S. An Economic Analysis, BNWL-23IT, Pacific Northwest Laboratory, August T977. 
15. Katter, J.B., Hoskins, R.L., Applications of Thermal Energy Storage to Process Heat and Waste Energy Recovery in the Primary ATuminum Industry, Cons/5080-T, October 1978.

16. Thermal Energy Storage Application Areas, TRW Energy Systems Planning Division, McLean, VA, March 1979.

17. Katter, L.B. and Peterson, D.J., Applications of Thermal Energy Storage Process Heat and Waste Heat Recovery in the Iron and Steel Industry, CONS/5081-T, October 1978.

18. Yeoman, John C., "A Net Energy Analysis of a Cogeneration-District Heating System and Two Conventional Alternatives," International District Heating Association Annual Conference, June 18-20, 1979.

19. McDonald, C.L., An Evaluation of the Potential for District Heating in the United States, Pacific Northwest Laboratory, November 1977, BNWL-SA-6259.

20. Oak Ridge Gaseous Diffusion Plant Reject Heat Study Final Report, Volume II I: Conceptual Designs and Economic Analyses, Exxon Nuclear Company, Inc., Richland, WA, September 1978.

21. Fox, E.C. and Thomas, J.F., A Preliminary Economic Analysis of Aquifer Water-Chill Storage at the John F. Kennedy Airport, ORNL/TM-6876, Oak Ridge National Laboratory, Oak Ridge, TN, December 1979.

22. Energy Information Administration Annual Report to Congress, 1978.

23. Solar Energy for Agriculture and Industrial Process Heat Program Summary, Energy Research and Development Administration, Division of Solar Energy, Washington, D.C., June 1977.

24. Hammer, Sorensen, F., "Actual Geothermal District-Heating Developments in Germany and Denmark," Geo-Heat Utilization Center Quarterly Bulletin, October 1979.

25. Intertechnology Corporation, Analysis of the Economic Potential of Solar Thermal Energy to Provide Industrial Process Heat, Volume I, Warrenton, VA, February 1977 .

26. Reistad, Gordon M., "Potential for Nonelectrical Applications of Geothermal Energy and Their Place in the National Economy," Proceedings, Second United Nations Symposium on the Development and Use of Geothermal Resources, San Francisco, CA, May 1975.

27. Lund, John W., "Alcohol Fuel Production Using Geothermal Energy," Geo-Heat Utilization Center Quarterly Bulletin, October 1979. 
28. Peart, Robert M., and Foster, George H., "Grain Drying with Solar Energy," International Solar Energy Society Extended Abstracts, ISES 75.

29. Larsson, Kje11, "District Heating: Swedish Experience of an Energy Efficient Concept," District Heating, April-May-June 1978.

30. Condap, Robert and Kydes, Andy S., Modeling Market Penetration with Emphasis on the DFI Energy-Economy System, Brookhaven Nationat Laboratory, BNL 50999, ApriT 1979.

31. International District Heating Association, "Statistical Committee Report of Industry Statistics for 1978," Official Proceedings, Seventieth Annual Conference of the International District Heating Association, Volume LXX, International District Heating Association, Pittsburgh, PA, June 1979. 


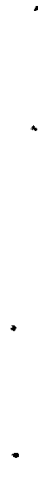


PNL -3298

UC-94a

\section{DISTRIBUTION}

No. of

Copies

OFFSITE

A. A. Churm

DOE Patent Division

9800 S. Cass Avenue

Argonne, IL 60439

J. Gahimer

DOE Office of Advanced Conservation Technologies

600 E. Street NW

Room 416, MS404

Washington, DC 20585

S. M. Hanson

DOE Office of Advanced Conservation Technologies

600 E. Street NW

Room 416, MS404

Washington, DC 20585

$R$. Jones

DOE Office of Advanced Conservation Technologies

600 E. Street NW

Room 416, MS404

Washington, DC 20585

G. Karadi

DOE Office of Advanced Conservation Technologies

600 E. Street NW

Room 416, MS404

Washington, DC 20585

G. F. Pezdirtz

DOE Office of Advanced Conservation Technologies

600 E. Street NW

Room 416, MS404

Washington, DC 20585
No. of

Copies

S. Strauch

DOE Office of Advanced Conservation Technologies

600 E. Street NW

Room 416 , MS404

Washington, DC 20585

J. H. Swisher

DOE Office of Advanced Conservation Technologies

600 E. Street NW

Room 416 , MS404

Washington, DC 20585

D. M. Eissenberg

Oak Ridge National Laboratory

P.0. Box $Y$

Oak Ridge, TN 37830

J. F. Martin

Oak Ridge National Laboratory

P.0. Box $Y$

Oak Ridge, TN 37830

Frank Baylin

Solar Energy Research Institute

1536 Cole Blvd

Golden, CO 80401

Charles Wyman

Solar Energy Research Institute

1536 Cole Blvd

Golden, C0 80401

Craig Cooley

Terra Tek

University Research Park

400 Wakara Way

Salt Lake City, UT 84108 
No. of

Copies

James W. Crosby III

Geo logy Department

Washington State University

Pullman, WA 99164

Mat Walton

Minnesota Geological Survey

319 15th Avenue S.E.

Minneapolis, MN 55455

Lou is Stern

Dames \& Moore

6 Commerce Drive

Cranford, NJ 07016

Melvin Singer

New York State Energy Research

\& Development Agency

Rockefeller Plaza

Albany, NY 12223

James C. O'Gara

Program Director, ATES

University of Minnesota

Physical Plant Operations

200 Shops Bldg.

319 15th Avenue S.E.

Minneapolis, MN 55455

J. M. Cherne

TRW

One Space Park

Redondo Beach, CA 90278

R. A. Duscha

NASA Lewis Research Center

21000 Brookpark Bivd

Cleveland, $\mathrm{OH} 44135$

E. R. Furman

NASA Lewis Research Center

21000 Brookpark B lvd

Cleveland, $\mathrm{OH} \quad 44135$
No. of

$\underline{\text { Copies }}$

Victor E. Hampe 1

Integrated Information Systems

Computation Dept., L-275

University of California

Lawrence Livermore Laboratory

P.0. Box 808

Livermore, CA 94550

Walter Hausz

GE-TEMPO

Center for Advanced Studies

816 State Street

P.0. Drawer QQ

Santa Barbara, CA 93102

Charles F. Meyer

GE-TEMPO

Center for Advanced Studies

816 State Street

P.0. Drawer QQ

Santa Barbara, CA 93102

Douglas D. Huxtable, Director

Energy R\&D

Rocket Research Company

York Center

Redmond, WA 98052

L. B. Katter

Rocket Research

York Center

Redmond, WA 98052

Charles H. Lee

Midwest Research Institute

425 Volker Blvd

Kansas City, MO 64110

Stanley N. Davis

Department of Hydrology and Water Research

University of Arizona

Tucson, AZ 85705 
No. of

Copies

David L. Schreiber, Ph.D., P.E. Consulting Hydraulic Engineer P.0. Box 1087

(c/o The Colony)

Coeur d'Alene, ID 83814

Donald Langmuir

Department of Chemistry and Geochemistry

Colorado School of Mines

Golden, CO 80401

Robert D. MacNish,

District Chief

Arizona District

U.S. Geological Survey

Federal Building

Tucson, AR 85718

Fred J. Molz

School of Engineering

Auburn University

Auburn, AL 36830

National Aeronautics and Space Adminstration Asst Adm for Energy Programs Washington, DC 20546

National Science Foundation Division of Advanced Energy Research and Technology

Room 1140

1800 G Street, NW

Washington, DC 20550

A. William Nice

NASA Lewis Research Center

21000 Brookpark Blvd

Cleveland, $\mathrm{OH} 44135$

Jerry J. Phillips

Projects Manger

Tennessee Valley Authority

350 Cormerce Union Bank Bldg

Chattanooga, TN 37401
No. of

Copies

L. Radosevich

Sandia Laboratories, Livermore

P.0. Box 969

Livermore, CA 94550

Donald L. Redde 11

Agricultural Engineering Dept.

Texas A\&M University

College Station, TX 77843

244 Technical Information Center

Sandia Laboratories

Technical Library Div. 3141

Albuquerque, NM 87185

John F. Spencer

Department of Ecology

State of Washington

01 ympia, WA 98504

Chin Fu Tsang

Bldg 90, Room 102-H

University of California

Lawerence Berkeley Laboratory

1 Cyclotron Road

Berkeley, CA 94720

Union Carbide Corporation

Nuclear Division

Attn. Library

$Y-12$ Plant

P.0. Box $Y$

Oak Ridge, TN 37830

U.S. Army Corps of Engineers

Attn: Library

P.0. Box 59

Louisville, KY 40202

U.S. Department of Energy

Attn: Chief, APMBR

Division of Energy Storage

Systems

Washington, DC 20545 
No. of

$\underline{\text { Copies }}$

U.S. Department of Energy
Attn: Director, Policy and
Planning
Office of Conservation and
Solar Applications
Washington, DC 20545

U.S. Department of Interior

Attn: Natural Resources Library Serials Branch (G/E)

Washington, DC 20240

William Waldrop

Assistant Branch Chief

Water Systems Development Branch

Division of Water Management

Tennessee Valley Authority

P.0. Drawer E

Norris, TN 37828

W. G. Wilson

Sandia Laboratories, Livermore

P.0. Box 969

Livermore, CA 94550

Charles Wyman

Solar Energy Research Institute

1536 Cole Blvd

Golden, CO 80401

\section{ONSITE}

3 DOE Richland Operations Office

D. K. Jones

H. E. Ransom

S. R. Sagstad
No. of

Copies

72 Pacific Northwest Laboratory

D. Blahnik

C. H. Bloomster

S. M. Brown

D. B. Cear lock

R. N. Coy

T. J. Doherty

J. R. Eliason

J. D. Etchemendy

K. Fox

W. A. Frier

D. L. Gale

A. F. Gasperino

P. L. Hendrickson

R. K. Johnson

C. T. Kincaid

W. W. Laity

L. R. Lambert

W. V. Loscutoff

R. P. Marshall

J. E. Minor (29)

D. A. Myers

M. E. Olson

J. R. Raymond (4)

R. W. Reilly

W. D. Richmond

B. L. Scott

J. A. Stottlemyre

R. Walter

G. E. Wukelic

STES Library (5)

Publishing Coordination (2)

Technical Information (5) 